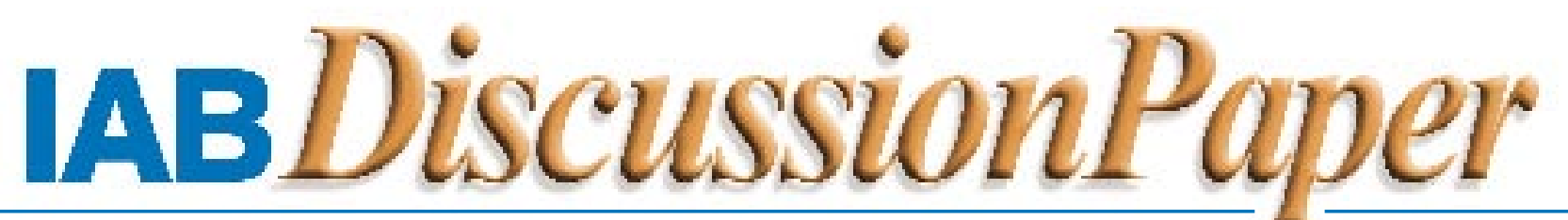

Beiträge zum wissenschaftlichen Dialog aus dem Institut für Arbeitsmarkt- und Berufsforschung

No. 6/2007

\title{
Activation Policies in Germany \\ From Status Protection to Basic Income Support
}

\author{
Regina Konle-Seidl, Werner Eichhorst, \\ Maria Grienberger-Zingerle
}




\title{
Activation Policies in Germany From Status Protection to Basic Income Support
}

\author{
Regina Konle-Seidl (IAB) \\ Werner Eichhorst (Institute for the Study of Labour, IZA, Bonn) \\ Maria Grienberger-Zingerle (Max Planck Institute for Foreign and \\ International Social Law, Munich, and Bavarian Ministry of Labour, Munich)
}

\begin{abstract}
Auch mit seiner neuen Reihe „IAB-Discussion Paper“ will das Forschungsinstitut der Bundesagentur für Arbeit den Dialog mit der externen Wissenschaft intensivieren. Durch die rasche Verbreitung von Forschungsergebnissen über das Internet soll noch vor Drucklegung Kritik angeregt und Qualität gesichert werden.
\end{abstract}

\footnotetext{
Also with its new series "IAB Discussion Paper" the research institute of the German Federal Employment Agency wants to intensify dialogue with external science. By the rapid spreading of research results via Internet still before printing criticism shall be stimulated and quality shall be ensured.
} 


\section{Contents}

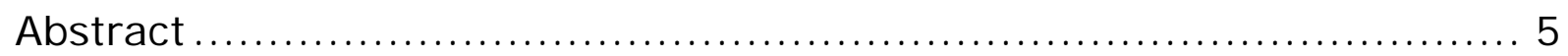

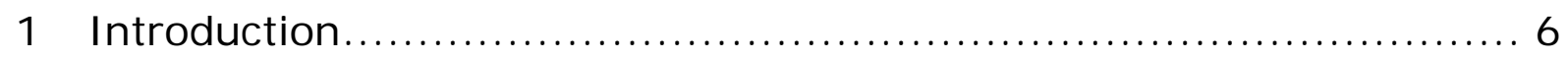

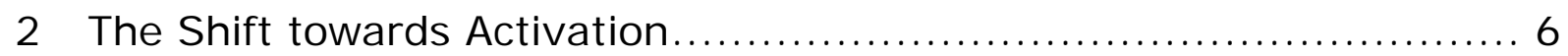

2.1 The Legacy of a Conservative European Welfare State ................ 6

2.2 The old system of unemployment benefits ........................... 7

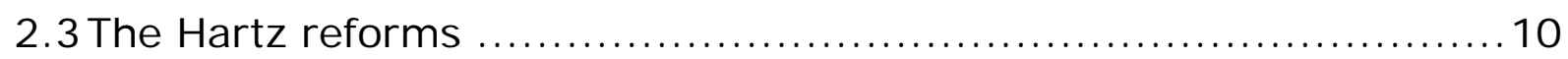

2.4 The political logic behind the policy shift ........................... 12

2.5 The Silent Change of the Welfare State Logic: From Bismarck to Beveridge? .......................................................... 16

3 Activating Labour Market Policy Today ................................ 18

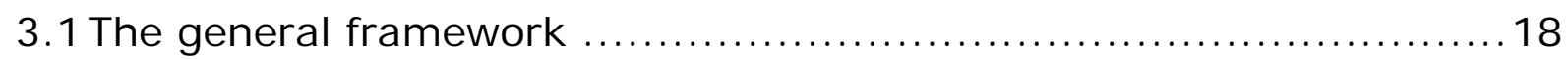

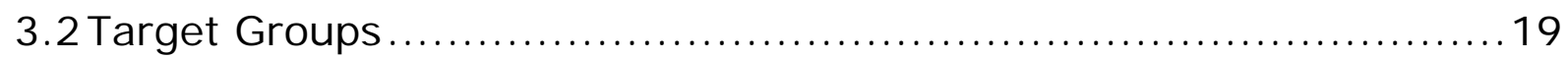

3.3 Demanding and promoting under SGB III (unemployment

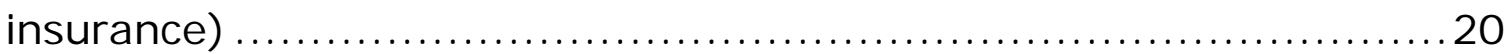

3.4 Demanding and promoting principles under SGB II (Basic Income

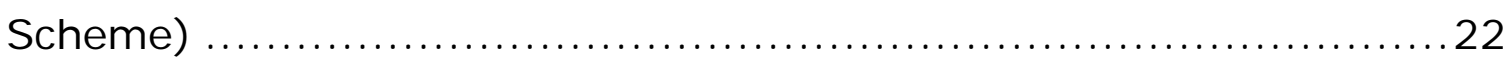

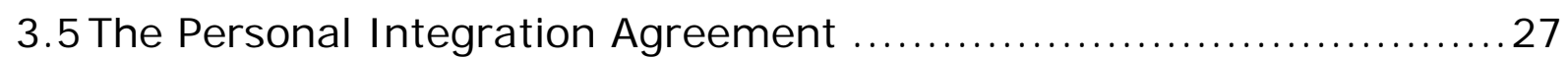

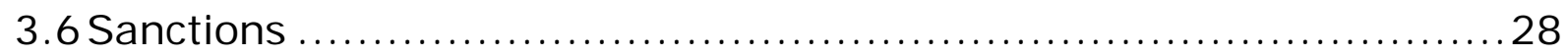

3.7 Activation Measures for UB I recipients ............................. 30

3.8 Activation Measures for UB II recipients ............................. 31

4 Constitutional Constraints to Activation................................ 32

4.1 Constitutional Guarantee of a Subsistence Minimum ...................33

4.2 The Property Guarantee ............................................. 34

4.3 Constitutional Guarantee of Free Choice of Occupation................ 35

5 Governance and Implementation ..................................... 37

5.1 Distribution of Competences ....................................... 37

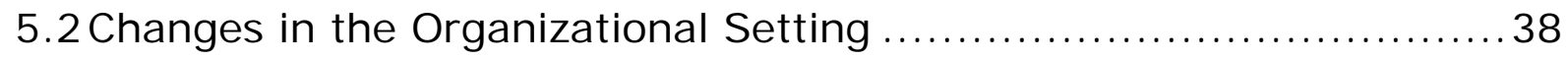

5.3 BA J obcenters for the Short-term Unemployed........................ 38

5.4 ARGE J obcenters and Municipal Agencies for the Long-term

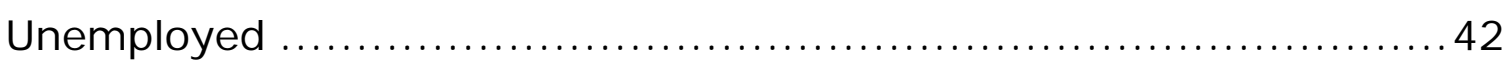

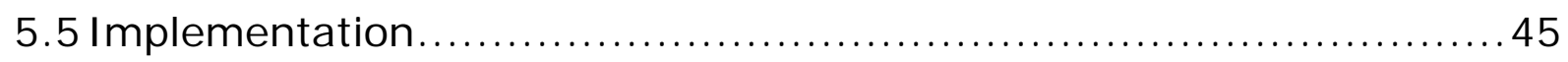


6 Outcomes of Activation: A Preliminary Assessment..................49

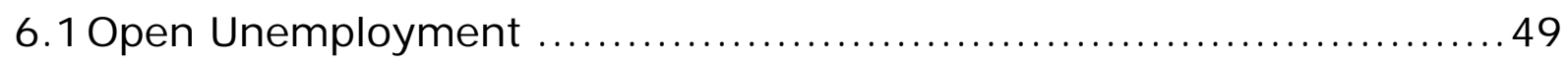

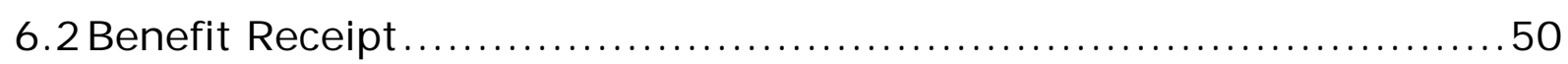

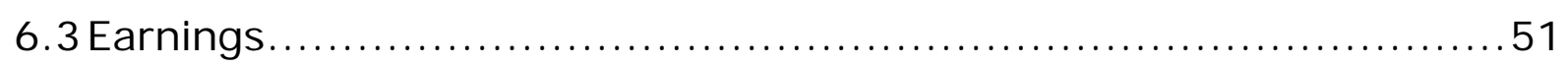

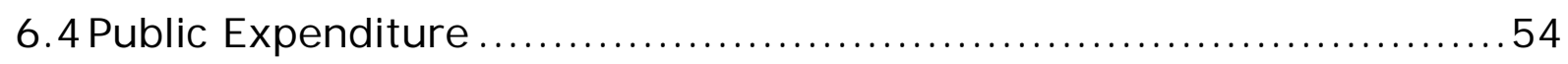

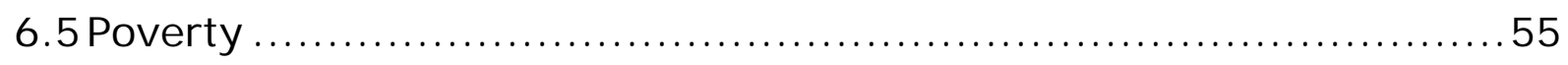

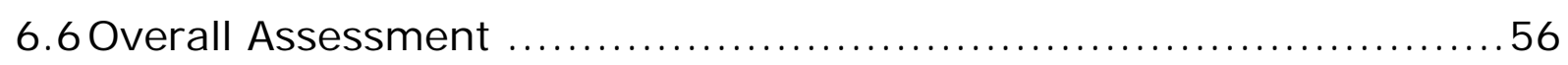

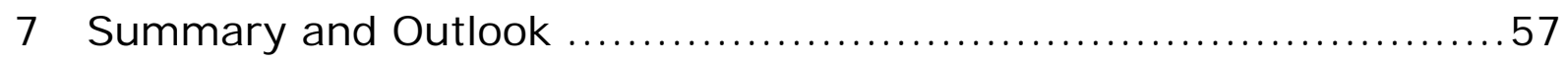

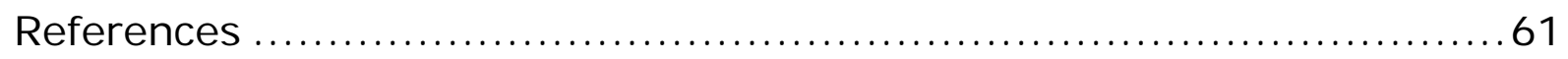




\begin{abstract}
This paper provides an overview of the sequential shift towards activating labour market and social policy in Germany. It not only shows the changes in the instruments of active and passives labour market policies but also analyzes the implications of this change for the political economy, the governance and the legal structure of a "Bismarckian" welfare state. Our study points at the changes in Germany's status- and occupation-oriented unemployment benefit regime that has been relinquished for a larger share of dependent population. Unemployment insurance benefit duration is shorter now and newly created basic income support for needy persons is not earnings-related anymore. Pressure on unemployed to take up jobs has increased considerably while more persons than before have access to employment assistance. The paper also aims at a preliminary assessment of the effects of activating labour market policy on labour market as well as social outcomes and sets out probable paths of future adaptation.
\end{abstract}

J EL-Classification: J 68

Keywords: activation, unemployment insurance, unemployment assistance, basic income scheme, active labour market policy, Germany 


\section{Introduction}

Although Germany has a long-standing reputation as a passive welfare state with elaborate schemes of status-protecting income replacement through social insurance in case of unemployment and a full-blown system of active labour market policies, all benefit systems had formal elements of activation and work requirement - but they had not been enforced systematically.

In recent years, however, reforms of active and passive labour market policy were implemented in Germany in order to create a more activating labour market and social policy regime and awake dormant activation principles. Changing the system of unemployment insurance benefits and basic income support as well as the repertoire of active labour market policy instruments and making benefit receipt more conditional upon job search and acceptance of job offers was a major issue on the political agenda. The reform of the benefit system also involved a major overhaul of the governance of labour market policy and has far-reaching implications for the logic of the German welfare state. All these reforms generated considerable public attention and interest from foreign observers. Yet, it remains to be seen to what extent activation is really implemented in practice and if the desired economic and societal objectives of activation could be achieved through the reforms adopted.

\section{The Shift towards Activation}

\subsection{The Legacy of a Conservative European Welfare State}

The German welfare state is typically depicted as the prime example of the conservative welfare regime, for which the preservation of social status is central (Esping-Andersen 1990). It has also been prominently characterized as a "frozen welfare state" highly resistant to change (Manow/Seils 2000). Facing a difficult economic environment since the mid-seventies, policy makers and social partners used active and passive labour market policies to reduce labour supply by taking "surplus labour" out of the labour market and shifting the unemployed to benefit schemes and active programs that were not effectively oriented towards swift reintegration into the labour market (Manow/Seils 2000). For some decades, active and passive labour market policies provided a "convenient" and "socially compatible" way of subsidizing entrepreneurial adjustment to dy- 
namic global markets and help stabilize competitiveness of manufacturing that was at the core of the German employment system (Streeck 1997) while at the same time facilitating a "social policy" approach to unemployment emphasizing income protection and "benevolent" treatment through active policies.

Availability of rather generous insurance based social benefits ${ }^{1}$ related to labour market status in the tradition of the "Bismarckian" model helped limiting income inequality and wage dispersion. Rather than creating a flexible and more inclusive labour market, the institutional arrangement of the German labour market of the eighties and nineties was conducive to limiting low-wage employment and wage inequality. This model focusing skilled labour was also stabilized by rather restrictive labour market regulation (Estevez-Abe/lversen/Soskice 2001).

Whereas this institutional pattern helped stabilize the core of the labour market, it also resulted in a strong segmentation of the labour market and high long-term unemployment. However, the German "high equality, low activity" equilibrium (Streeck 2001) resulted in an ever increasing burden of non-wage labour costs as a growing number of benefit recipients in the labour market directly translated into rising social security contributions and fiscal pressure on the state budget that was used to cover deficits in social insurance. Thus, the sustainability of the German "welfare state without work" (Esping-Andersen 1996) was at risk as it tended to erode its own financial basis in particular facing increasing pressure on wage costs stemming from more intense international competition (Manow/Seils 2000).

\subsection{The old system of unemployment benefits}

Prior to the Hartz reforms that came into force between 2002 and 2005, Germany had a three-tier system of income protection in case of unemployment:

1. Unemployment insurance benefit (UB, Arbeitslosengeld) provided earnings-related income replacement for a limited duration of up to 32

1 The net replacement rate for an average production worker in the initial phase of unemployment in 2002 was 61 percent in Germany compared to 45 percent in UK, 55 percent in Austria, 59 percent in Denmark and 71 per cent in France (OECD 2004). 
months if unemployed had been in employment covered by social insurance for at least 12 months. Unemployment insurance benefits were funded through employer and employee contributions and administered by the Federal Employment Agency which was also in charge of implementing active labour market policies.

2. Unemployment assistance (UA, Arbeitslosenhilfe) was a system of means-tested, but earnings-related benefits for long-term unemployed after the expiry of unemployment insurance benefits. Hence, it provided income support for unemployed people who had some prior employment experience but had become long-term unemployed. Unemployment assistance was granted for an unlimited period and funded through the Federal budget, i.e. by general taxation. This scheme was also implemented by the Federal Employment Agency, with recipients of unemployment assistance in principle having access to similar active labour market schemes as UB I recipients.

3. Social assistance (SA, Sozialhilfe), finally, provided basic income protection on a means-tested and flat-rate basis for all German inhabitants - with or without employment experience - who could not rely on sufficient resources from earned income, other social benefits or family transfers. Thus, social assistance was the major protection system for unemployed with either no employment experience or unemployment insurance/unemployment assistance claims that did not match the guaranteed minimum income. Social assistance was funded by the municipalities that were also responsible for reintegrating recipients into the labour market through specific active measures.

In comparison to the unemployment assistance scheme, means-testing was harsher in the social assistance scheme, moreover, every job was considered acceptable. For labour market integration of employable social assistance recipients, a fairly rudimentary labour market policy, the "Help to Work" scheme, was available. It was operated by the municipalities with a considerable scope of discretion. There was no entitlement to integration measures by the Public Employment Service (PES).

All systems had formal elements of activation and work requirement, but this was not enforced systematically in practice. For example, the „Help to Work Scheme" (Hilfe zur Arbeit) incorporated in the Social Assistance Act 
( $\S 18$ to 20 BSHG) was based on the "rights and obligation" principle. The BSHG nevertheless failed to state specific provisions on the reasonability of job offers. Court rulings have tended to show that a protection of former occupational status no longer exists. Personal grounds are above all seen in age or sickness, while familial grounds mainly take account of a single parent's care of a child under the age of three. Despite the fact that the law on social assistance called for individual efforts to search for work in order to be able to become independent from public assistance, activating interventions were not implemented systematically. Some local authorities have been able to achieve remarkably good results in reintegrating assistance applicants under the "Help to Work" scheme. However, the intensity of activation differed strongly between municipalities, and many local authorities placed social assistance recipients in work opportunities that were covered by social insurance in order to create new entitlements to unemployment insurance benefits and unemployment benefits (Schneider et al. 2002). This proved to be an effective way of shifting the burden of transfer payment to unemployment insurance. The fact that the two predecessor schemes of the current Unemployment Benefit II were subject to different rules and administered by different administrations posed the described problems that hampered efficient activation of recipients.

Whereas the entitlement to unemployment benefits were extended in the mid 80s eligibility and suitability criteria in unemployment insurance, however, were tightened step by step over the nineties. The formal strictness of the unemployment protection regime was increased as legal provisions on benefits being conditional upon willingness to work and accept jobs not equivalent to prior qualification were reformulated in a more restrictive direction with occupational protection being revoked completely in 1997. The main motivation, however, was not effective activation, but shortterm fiscal stabilization. At the same time, access to benefits became slightly more difficult, and benefit generosity was reduced marginally. Nevertheless, a rather "permissive" and benefit-cantered approach to unemployment was still dominant in practical implementation. Moreover, although evaluation studies in the nineties provided evidence that the extension of the length of entitlement in the 80s was associated with an increase in unemployment duration, there was no change in entitlement periods in the nineties (Hunt 1995, Steiner 1997, Launov et al 2004). 


\subsection{The Hartz reforms}

With the number of recipients of UA and SA benefits steeply rising, largely due to a continuous increase in long-term unemployment, reforming these systems became a priority on the agenda of labour market and social policy. In the late nineties, the problem of fiscal disincentives was more widely discussed, thus paving the way to some pilot projects on joint initiatives of local PES and municipal social assistance offices to reintegrate the long-term unemployed into the labour market ("Mozart initiative"). This was followed by the JobAqtiv Act of late 2001 that aimed at a more coherent activation principle in Germany labour market policies for the first time. However, the moderate attempt of J obAqtiv was superposed by the PES placement scandal ${ }^{2}$ and the work of the Hartz commission, a government-initiated expert committee that present its report in August 2002. This report formed the base for a package of reforms aiming at activating both short- and long-term unemployed, reforming the PES and the institutional repertoire of active schemes. Finally, with the fourth Hartz Act (Hartz IV) coming into force in January 2005, unemployment assistance and social assistance were replaced by a single means-tested replacement scheme for persons in need and able to work (UB II) not entitled to unemployment insurance benefit or after expiry of this contribution-based benefit (UB I).

Besides UB II, the new basic income scheme provides social allowance (Sozialgeld) to persons who live together with needy persons capable of working in a joint household (a so-called Bedarfsgemeinschaft) ${ }^{3}$. The recipients of social allowance are normally kids below the working age of 15

2 In February 2002 the Federal Audit Court discovered that the placement statistics of the Federal Labour Office, the "Bundesanstalt für Arbeit", were wrongly reported. As a result of this scandal the government presented a reform plan and set up an expert commission, named after its chairman, Peter Hartz, the human resource director of Volkswagen.

3 The term Bedarfsgemeinschaft includes: the needy persons capable to work; the partner living in the household, or the parent, respectively, of an under-age, unmarried employable child and this parent's partner living in the household; the not permanently separated spouse as partner of the employable person in need of assistance; the person living with the employable person in need of assistance as a cohabiting partner; the partner not permanently living apart from the employable person in need of assistance; the under-age unmarried children belonging to the household of the aforementioned persons to the extent that they are unable to procure their means of subsistence from their own income or assets. 
years. Those incapable of work receive social assistance according to Book Twelve of the Social Code (SGB XII) which continues to be the responsibility of the municipalities (see table 1 ).

Hartz IV radically changed the German system of wage-related welfare. The new Unemployment Benefit II scheme has a dual aim: on the one hand it was designed to prevent poverty but not to secure previous living standards. Thus, for those having received social assistance before, the new legislation actually allows them to receive marginally more money and access to job employment services. For former recipients of unemployment assistance the level of transfer payment decreased.

Table 1: The Old and the New Benefit System

\begin{tabular}{|c|c|}
\hline Old System (until 2004) & New System (2005 -) \\
\hline $\begin{array}{l}\text { Arbeitslosengeld (unemployment insur- } \\
\text { ance benefit): funded through contribu- } \\
\text { tions, earnings-related, limited duration }\end{array}$ & $\begin{array}{l}\text { Arbeitslosengeld I (UB I): funded through } \\
\text { contributions, earnings-related, limited duration }\end{array}$ \\
\hline $\begin{array}{l}\text { Arbeitslosenhilfe (earnings-related } \\
\text { unemployment assistance): tax-funded, } \\
\text { earnings-related, means-tested, infinite } \\
\text { duration }\end{array}$ & $\begin{array}{l}\text { Grundsicherung (Basic income scheme for } \\
\text { needy jobseeker/ SGB II)) } \\
\text { Consisting of } \\
\text { a) Arbeitslosengeld II (UB II): tax-funded, } \\
\text { means-tested, flat rate, after expiry of UB I } \\
\text { (and temporary supplement), infinite dura- } \\
\text { tion (integration of "Arbeitslosenhilfe" and } \\
\text { "Sozialhilfe" for people capable of working ) } \\
\text { but stronger principle of activation } \\
\text { b) Sozialgeld (social allowance) for kids below } \\
\text { the working age of } 15 \text { living in a household } \\
\text { of an UB II recipient }\end{array}$ \\
\hline $\begin{array}{l}\text { Sozialhilfe (social assistance): tax- } \\
\text { funded, means-tested, flat rate, infinite } \\
\text { duration }\end{array}$ & $\begin{array}{l}\text { Social assistance: means-tested, tax-funded, } \\
\text { flat rate, infinite duration (SGB XII) } \\
\text { Consisting of } \\
\text { - Grundsicherung für Erwerbsgeminderte und } \\
\text { im Alter: } \\
\text { for those working age people above } 18 \\
\text { years permanently not capable of working } \\
\text { and for needy persons above } 65 \text { years } \\
\text { - Hilfe zum Lebensunterhalt } \\
\text { Help to overcome special situations in life } \\
\text { (illness, care etc) }\end{array}$ \\
\hline
\end{tabular}

Apart from its social policy objective, the aim of this reform was to lower unemployment but also to ease the burden of taxation and non-wage labour costs by reducing benefit dependency. The major lever to achieve this goal was the shortening of individual unemployment spells through 
accelerated job placement and more coherent activation of the beneficiaries of unemployment insurance benefits and unemployment or social assistance. Less generous benefits for long-term unemployed, stricter job suitability criteria and more effective job placement and active labour market schemes were the instruments to achieve this goal. However, as termination of need is the core objective, there is no formal labour market availability criterion. But benefit recipients can be demanded to take up any job and follow obligations stemming from integration agreements.

For activation to become an effective answer to benefit dependency, the labour market, however, must improve its capacities to create jobs (Eichhorst/Konle-Seidl 2007). Therefore part of the Hartz package was devoted to a (limited) flexibilization of the labour market (J acobi/Kluve 2006, Eichhorst/Kaiser 2006). This was not right at the core of activating labour market policy, but should facilitate it.

The practical enforcement of "rights and duties", however, is the core element of the Hartz reforms. The activation strategy is implemented in virtually every element of the labour market policy framework. The Hartz reforms shift priority towards active measures that require proactive behaviour of the unemployed and promote their direct integration into regular employment. To this end, the reform re-designed integration subsidies, introduced new forms of wage subsidies, start-up subsidies and jobs with reduced social security contributions.

\subsection{The political logic behind the policy shift}

Germany's rather late, but broad and massive shift to activation or - more precisely - awakening of "sleeping" activating principles was the direct result of a long period of reform blockage and postponement in labour market policy. One explanation is German reunification. As a consequence of reunification in Germany, not the restructuring, but the expansion of traditional instruments of active labour market policies, particularly job creation schemes, but also passive income support was on the agenda in the beginning of the 1990s (Manow/Seils 2000). Another explication refers to the strong role of social partner self-administration in the Public Employment Service (Trampusch 2002) that were interested in controlling resource allocation to favour their clientele, take "surplus labour" out of the labour market and shift it to active and passive labour market policies 
and other social benefit schemes while deficits in unemployment insurance were covered by the federal government or higher contributions.

Although this resulted in rising non-wage labour costs which in turn hampered employment creation. Despite the fact that rather critical evaluation studies on active labour market policies and employment disincentives in benefit systems, a more fundamental overhaul of active and passive labour market policies was virtually a non-issue in the Germany political economy until the early years of the current decade. Reforms in this area would have questioned the implicit "social treatment" of unemployment and implied a more prominent role of low-wage employment as a tool of labour market re-entry for the long-term unemployed as well as a more general flexibilization of the labour market.

The Red-Green coalition government that came into power in 1998 was divided on this issue, with the major fragmentation between different wings of the Social Democratic Party. On the one hand, the new government revoked some of the restrictive provisions of the prior ChristianDemocratic/Liberal government and tried to stabilize the "social policy" approach to unemployment. On the other hand, it tried to develop a more coherent normative framework for labour market and welfare state reforms referring to the concept of the "activating state" which was mainly inspired by New Labour and "third way" approaches formulated in the United Kingdom (Giddens 1999).

The concept of the "activating state" would have meant focusing public interventions on "enabling" programs that could help individuals take their own responsibility. In labour market policy, this implied stressing the conditionality of benefits upon individual efforts and cooperation, thus emphasizing the fundamental symmetry of "rights and obligations". As it would also mean a break with the tradition of a status-protecting and occupation-oriented welfare state, this concept met only limited acceptance and strong opposition from major fractions within the Social Democrats. Maybe the best example for this reluctance is the rejection of the alleged "neo-liberal" Schröder/Blair paper in 1999. Hence, activation could not become a more systematic point of reference or an elaborated concept in the early years of the Red-Green coalition. 
Reform stalemate could only be overcome in the face of the window of opportunity of the "placement scandal" and the subsequent Hartz report in 2002 with an expert commission legitimizing further reforms of labour market policy and regulation, changing the role of social partner tripartism in BA and national policy-making, thus paving the way for more determined government action (Eichhorst/Kaiser 2006, Streeck/Trampusch 2005).

Activation was reintroduced by the report of the Hartz Commission who made references to good practices at the national levels, e.g. models of effective cooperation between BA and municipalities in selected "Mozart" projects, as well as international "best practices" and benchmarking of labour market performance and policies. Hence, the Hartz reforms focus was inspired by activating policies for the unemployed in other European countries that were perceived to be more successful in lowering unemployment such as the United Kingdom, the Netherlands or Denmark (Bruttel/Kemmerling 2006, Eichhorst/Profit/Thode 2001, Fleckenstein 2004).

The government's willingness to implement the Hartz proposals in a comprehensive way implied further clarification of crucial issues such as the level of the unified benefit for long-term unemployed that was to replace unemployment assistance and social assistance for people capable of working (erwerbsfähig). With the "Agenda 2010" announced in March 2003 in a situation of high and rising unemployment and considerable political pressure it became clear that the government would opt for a flatrate benefit with about the same level as social assistance thus effectively severing the link with prior earnings. This was to be implemented with the fourth Hartz Act (Hartz IV) in January 2005. In addition, the government announced shortening unemployment insurance benefit duration for older workers from 32 to 18 months and to cut dismissal protection and other elements of labour market regulation ( J antz 2004).

This sequence of rather "harsh" reforms that were perceived as a break with traditional social policy approach to labour market problems provoked broad public unrest that eventually resulted in a significant decline in political support for the red-green coalition, in particular the Social Democ- 
rats, the emergence of a new left-wing party and the electoral defeat of Red-Green Coalition in autumn 2005 (Eichhorst/Sesselmeier 2006). ${ }^{4}$

The opposition was strongest in the Eastern part of Germany (Rucht/Yang 2004). There, long-term unemployed people could rely on relatively high and unlimited payments of unemployment assistance due to widespread full-time employment of both men and women in the former GDR. Hence, abolishing earnings-related benefits, replacing them with flat-rate benefits and introducing a stricter activation policy was perceived as a threat to individual well being in particular given the poor labour market perspectives in East Germany.

Therefore, Hartz IV was perceived as a "social cruelty" that would result in severe benefit cuts, increasing poverty, strict supervision of jobseekers and forcing people in low-wage jobs, thus leading to a growing number of "working poor" and a tacit "Americanization" of the German labour market, something that had to be avoided by any means in the past. Thus, Hartz IV became the symbol for a policy that was seen as a break with the principle of "the social insurance state" of providing status-oriented benefits while imposing only limited demands on unemployed.

Even to date, there is no societal consensus on policy objectives in labour market policies. Hence, the paradigm shift to activation is not complete yet. Moreover there is a dominating sense of injustice. It is fair to argue that the broad rejection of the Hartz IV-reform is due to a fundamental deficit of legitimating the "hidden" or silent shift from a social insurance state to a welfare state dominated by basic income support and stronger activation.

4 This was also due to the fact that Hartz IV led to a change in unemployment statistics. The introduction of UB II implied new eligibility criteria for benefit receipt. One criterion is that recipients have to be "capable of working at least three hours a day". Moreover, the non-working partners of benefit claimants were obliged for the first time to register as unemployed. Therefore, a large number of former social assistance recipients, previously not registered as unemployed, were counted in January 2005 in the unemployment statistics. In turn, the number of registered unemployed exceeded 5 million for the first time in Germany. Although this was only a statistical effect and did not mean a substantial increase in non-employment or broad unemployment, it was perceived as a major policy failure and the proof of the fact that the Hartz reforms did not work. 


\subsection{The Silent Change of the Welfare State Logic: From Bismarck to Beveridge?}

Despite on-going reforms since the mid-1990s, it is frequently argued that the Hartz IV law marks a critical juncture resulting in the departure from a conservative welfare state securing acquired standard of living and a move towards an Anglo-Saxon welfare state relying on means-tested welfare and securing only basic needs. In fact, the Hartz IV reform is part of gradual shift from "Bismarck" to "Beveridge" in that it weakened the principle of status protection and contribution-equivalence in unemployment benefits for the long-term unemployed and strengthened the role meanstested flat-rate benefits providing a minimum income floor only. However, stricter means-testing and flat-rate benefits imply a higher degree of interpersonal redistribution. Table 2 shows the relationship between recipients of contribution-based and means-tested flat-rate benefits in 2005 .

Table 2: Contribution-based and means-tested unemployment benefits (2005)

\begin{tabular}{|l|c|c|}
\hline Type of benefit & Number of recipients & $\begin{array}{c}\text { In percent of working } \\
\text { age population }\end{array}$ \\
\hline Insurance scheme (UB I) & 1.730 .000 & $3 \%$ \\
\hline $\begin{array}{l}\text { Means-tested scheme } \\
\text { (UB II) }\end{array}$ & 4.980 .000 & $9 \%$ \\
\hline Total UB I and UB II & 6.710 .000 & $12 \%$ \\
\hline
\end{tabular}

Source: Bundesagentur für Arbeit.

To secure social status and the acquired standard of living, the unemployment benefit and the previous unemployment assistance referred to the former income. The duration of the unemployment benefit varied strongly according to age. Until early 2006 drawing benefits for up to 32 months was possible for older workers, thus stressing a widely perceived "savings account logic" of unemployment insurance. In the old system, a person becoming unemployed was entitled to unemployment insurance benefits for a certain period if he/she had an employment record of at least one year during the past few years. This benefit initially amounted to more than two thirds of the previous income with an in-build ceiling in accordance to the "equivalence principle", and thus "rewarded" prior earnings and effort. The higher an individual's achievements during his or her employment career, the higher the benefits. Older workers with a longer 
employment record could rely on extended unemployment insurance benefits.

When unemployment benefits were exhausted, the unemployed could apply for unemployment assistance which was still related to previous earnings but on a lower level. Although unemployment assistance was taxfunded, it was seen as a prolongation of unemployment insurance benefit (Karl/Ullrich/Hamann 2002). The "equivalence principle" was complemented by the principle of "occupational protection" that defined the "suitable job" an unemployed person had to accept as more or less adequate to the position held before becoming unemployed. Last but not least, persons relying on unemployment insurance benefits could also benefit from heavy investment in "enabling" active labour market policy schemes. These programs were not primarily used as a work-test but as instruments to stabilize human capital and restore benefit claims.

Hence, removing occupational protection (as early as in 1997), but more specifically, shortening benefit duration in unemployment insurance for older workers and abolishing earnings-related unemployment assistance means a departure form status protection and the strong reliance on the insurance principle and the equivalence of contributions and benefits. Abolishing longer benefit durations for older unemployed and earningsrelated unemployment assistance was seen as an "expropriation". As the reform interfered with widely accepted principles of "social justice" embodied in an insurance-based system, this change was perceived as "unfair" in particular given the fear of increased economic pressure not only due to lower and less sufficient benefits but also due to the announcement of stricter activation and placement even in low-wage jobs. While such prospects are well established and generally accepted in countries like the United States or the UK, they mean an overhaul of established notions of the German social model which strongly rests on what could be called "social security citizenship" (Ludwig-Mayerhofer 2005) ${ }^{5}$.

5 Moving from extended social insurance through earnings-related benefit both in unemployment insurance and unemployment assistance also means a weakening of the traditional conservative "bread winner" model that was applied not only to the employed but also to the unemployed. The new basic income support does not take into account derived family responsibilities but generated individual entitlement for part- 
Labour market policies in Germany helped to create and sustain the illusion that the "implicit contract" of rewarding previous contributions of the unemployed to the German economy - through benefits and labour market measures - was still intact. In fact, this contract had been undermined to a considerable degree for an increasing number of long-term unemployed who, in addition to their often meagre Arbeitslosenhilfe, had to rely on Sozialhilfe payments, thus receiving financial support that was only related to "need" and not to previous labour market achievement.

\section{Activating Labour Market Policy Today}

\subsection{The general framework}

The first and foremost objective of activating labour market policy in Germany is the reduction of individual unemployment duration by bringing unemployed persons, in particularly the long-term unemployed, back to work.

The basic principle of activating labour market policy in Germany is "Fördern und Fordern", i.e. enabling or supporting the jobseekers on the one hand and demanding individual effort on the other. The recent reforms are in fact a recalibration of the Janus-faced nature of the German welfare state emphasizing both the role of demanding provisions (Fordern) and the enabling or empowering elements of social and labour market policy (Fördern). While these principles have been in place for some time under former social assistance and in the well established active labour market policy framework, what is new is a tighter conceptual and practical linking of promoting and demanding elements (Fördern durch Fordern). These general orientations were explicitly fixed in the new SGB II (Second Book of the German Social Security Act, Sozialgesetzbuch II).

The concept of individual "co-production" for needy persons "capable of work" replaces the former paternalistic model. As participation in the labour market is assumed to be the high road to societal integration, taking

ners/spouses and children, thus furthering individualization of welfare claims and stressing job search requirements for all employable members of a needy household and breaking with a more conservative family model (Knuth 2006). 
up work is superior to receiving passive benefits only. Formal terms defining the basic orientation of German activating labour market policy, however, open up ample space for divergent interpretations that are crucial for actual implementation.

Complementary to activating instruments in a more narrow sense, SGB II comprises enabling schemes such as labour market policy programs ( $\S 16$ (1) SGB II) and other social services like child care provision or help in case of social problems like drug abuse, debt or housing ( $\$ 16$ (2) SGB II) that have been conceived in order to facilitate labour market integration of employable benefit recipients, but do not reinforce benefit conditionality.

\subsection{Target Groups}

Activating measures address foremost the target group of unemployed persons - both UB I and UB II recipients. To avoid long-term unemployment, which begins after 12 months according to both the German and the European definition, these persons have to register promptly with the local employment offices as soon as unemployment is foreseeable.

The medical definition of "capability to work" (not employability) with three hours a day in the foreseeable future under the usual conditions of the labour market results in a rather broad demarcation of the target groups which exceeds the focus of activation in many other European countries. This contributes to higher figures of open (registered) unemployment while in other countries a narrow definition of employability means fewer people registered as unemployed but assigned to passive schemes such as disability benefits.

The "capability of working" (Erwerbsfähigkeit) features prominently as the overall concept of this approach. The individual working ability is evaluated purely from a medical standpoint. It is decided by the institution responsible for the safety net, i.e. usually the local employment office.

Certain sub-groups of persons "capable of working" are exempted from the availability criterion under the unemployment insurance regime (UB I), and the conditional job search requirement under basic income support (UB II). This holds for sick people and for persons that care for children less than 3 years old or care for family members as well as for older per- 
sons (so called 58er-Regelung). However, there is a contradictory approach regarding to older persons with some enabling schemes on the one hand (wage subsidies and wage insurance) and the clause exempting them from the obligation to be available for work. Accordingly, these persons receive public support but are not obliged to seek or accept employment - nor are they recorded as unemployed in the statistics (Eichhorst 2006).

Persons with disabilities form an additional group at the core of the legislator's activating strategy. These persons are not subject to the same requirements as other unemployed persons, in particular their rights to support are less tightly linked to duties. The prime objective since many years, however, is to promote participation in working life. The principle of supporting rehabilitation measures instead of paying passive income support for disabled people is a basic feature of German active labour market policy. Furthermore, access to passive schemes like disability allowance is rather restrictive and not seen as an attractive "escape route" like in most other European countries (Konle-Seidl/Lang 2006). ${ }^{6}$

\subsection{Demanding and promoting under SGB I I I (unemployment insurance)}

The role of demanding and promoting elements (Fördern und Fordern) differ with respect to individual rights and obligations between unemployment insurance (Third Book of the Social Security Act, SGB III) and basic income support (Second Book of the Social Security Act, SGB II).

The claim to unemployment benefit under $\S 118(1)$ SGB III arises in the event of unemployment and further vocational training. Workers entitled to unemployment benefit must be unemployed and registered with the employment office and must have fulfilled the qualifying period.

Unemployed persons pursuant to $\S 119(1)$ SGB III are persons without work, seek to end their unemployment (personal efforts) and are available

6 This means that the share of recipients registered as unemployed and included in mandatory job search activities or activation programs is higher in Germany $(12,1$ percent of working age population) and that of "inactive" recipients of passive insurance and welfare benefit schemes (3,5 percent of working age population) lower than in other countries. 
for the placement efforts of the Employment Agency (availability). Persons are considered to be without work if they do not work at all or if they work less than 15 hours per week. To be available, the unemployed person must be capable of work and be prepared to work, i.e. have the subjective will to work.

An important aspect of job-seeking is that unemployed persons only have to accept and search for work that can be reasonably expected of them (§§ 119(5) no. 1, 121 SGB III). The extent of this restriction on the seeking of reasonable work is largely influenced by the courts, which interpret it on the basis of particular case decisions.

The amount of unemployment benefit is regulated in § 129 SGB III and depends on family status, wage-tax bracket and weekly remuneration. Accordingly, insured persons with at least one child are entitled to 67 percent or, without children, to 60 percent of net remuneration fixed as a lump sum. Unemployment insurance claims are based on an employment record and provide for benefits proportional to prior earnings in the reference period. It does not take individual means or need into account.

Unemployed persons must through their own personal efforts utilise all possibilities available for their occupational integration ( $\S 119$ (4) SGB III). These efforts include the performance of duties set forth in the integration agreement, participation in third-party placement services and the use of self-information facilities provided by the Employment Agencies.

The concept of personal effort bears activating features in that the search for employment is a precondition for the receipt of unemployment benefit. The nearest sanction for lack of personal effort is the imposition of a disqualification period. Unemployed are deemed available for the placement efforts if, inter alia, they are capable of and allowed to exercise an occupation which can be reasonably expected of them under the usual conditions of the labour market to be considered by them, and which is subject to compulsory insurance and comprises a weekly working time of no less than 15 hours. An important criterion of this definition is "suitability", which is detailed in $\S 121$ SGB III and purports that an unemployed person can be expected to perform all occupations conforming to his or her working capabilities to the extent that general or personal grounds do not oppose the reasonability of an employment. 
However, in contrast to basic income protection, not all jobs are considered suitable for unemployment insurance beneficiaries. There is not only a minimum threshold of 15 hours per week, but also a minimum level of earnings to be achieved that is related to prior wages and to the benefit levels. In earlier times, the protection of an acquired earnings level and occupation was even stronger. But the principle of occupational protection had been eroded to a considerable degree in 1997 when new legislation stipulated that after six months of unemployment any job was suitable that provides at least earnings equivalent to unemployment compensation.

Nevertheless, until 1998 it was possible to stabilize and renew claims for unemployment insurance benefits through participation in publicly funded training programs and until 2003 in direct public job creation. These possibilities are cut now and additionally the Hartz legislation strengthened availability criteria by defining removal reasonable and just in case of single unemployed and by shifting the burden of proof in case of rejection of job offers to the unemployed. Last but not least, the cut in maximum benefit duration for unemployed under 54 years from maximum 26 months to 12 months and from 32 to 18 months for unemployed aged 55 and over (effective since 1 February 2006) and to means that older unemployed move to means-tested basic income support earlier in their unemployment spell.

\subsection{Demanding and promoting principles under SGB I I (Basic I ncome Scheme)}

Basic income support for needy jobseekers (Grundsicherung für Arbeitsuchende) has the double aim of

a) providing sufficient minimum resources to ensure a decent standard of living in order to avoid poverty and

b) Ending benefit dependency through reintegration into gainful employment.

Basic income support for jobseekers is awarded under § 7 SGB II to persons who have attained the age of 15 but are still under 65, are capable of gainful employment, in need of assistance and have their customary place of abode in the Federal Republic of Germany. 
According to $\S 1$ Abs. 1 SGB II "people capable of working" should overcome need through their own efforts and their own means. An individual is needy if he/she is unable to earn a living for him/her and for the other family members living together in one household. The individual in question is required to take on an acceptable job and use his own income and (certain) assets as well as that of his/her partner. Legislation on basic income support (SGB II) pursues foremost social objectives. It provides a needs-oriented income so that all needy persons in Germany have sufficient means of subsistence.

Although basic income support for needy jobseekers is foremost a genuine social policy program to avoid poverty it has a strong focus on the labour market. With Hartz IV the interface of social and labour market policy has been redefined and the traditional divide between both policy areas eroded. It focuses on need (not on unemployment as such) and on interventions to reduce need - with attempts at labour market integration featuring prominently as a promising way to end benefit dependency.

Thus, the new regime of basic income points at personal responsibility and at enabling and supporting interventions in order to enhance individual capacities to overcome need. Labour market availability and willingness to take up any job - even below wages set by collective agreements or public employment opportunities - are therefore crucial elements of activation addressing recipients of basic income support as long as they are capable of work. At the same time, however, UB II recipients can keep their benefit if they take up low-wage jobs that fit into the earnings disregard clause. The current provision stipulated that the first EUR 100 of monthly earnings are not taken into account when benefits are calculated whereas between EUR 100 and 800 20\% remain with the beneficiaries as is true for $10 \%$ of earnings between EUR 800 and EUR 1.200 for singles or EUR 1.500 in case of UB II recipients with children.

Pursuant to $\S 19$ SGB II, UB II consists of benefits to secure subsistence, including reasonable costs of accommodation and heating, and a fixedterm supplementary allowance under $\S 24$ SGB II, which is to cushion the transition from unemployment assistance to Unemployment Benefit II. It's an additional benefit that provides two thirds of the difference between UB I and UB II for twelve months and one third for an additional year. 
The normal benefit under $\S 20(2)$ and (4) SGB II is a lump-sum amount that is supposed to cover all living expenses. From 1 July 2006, this amount has been fixed at a standard rate of EUR 345 throughout the federal territory. Benefits for accommodation and heating are specified in $\S 22$ SGB II. Their amount is equivalent to the actual expenses, provided these are reasonable.

This standard payment is higher than the social assistance benefit (EUR 295 since July 2004). For children the standard payments are lower. Nevertheless SA benefits included more additional payments than UB II. In comparison to former unemployment assistance (on average EUR 550 in 2003 in Western Germany) UB II is less generous. This should result in pressure on the jobless to take on work. However, it should to be taken into account that, whereas the recipients of UB II receive payments for housing and heating, the former UA recipients could only qualify for supplementary housing and social assistance if they fulfilled special conditions.

Hence, contrary to widespread beliefs, the new UB II is not in general lower than means-tested benefits prior to the Hartz IV reform. This holds for virtually all former social assistance beneficiaries, but also for a relevant share of all former unemployment assistance recipients. Simulation studies show that about one sixth of them lost its benefit entitlement due to the stricter consideration of wealth or earned income. Of the remaining persons with continued benefit claims, about 47 percent receive higher benefits, and about 53 percent have net losses (Blos/Rudolph 2005). Former unemployment assistance beneficiaries are affected unequally, however, with net gains concentrated among the young and the lone parents while older beneficiaries and couples with relatively high benefits under earnings-related unemployment assistance suffered from considerable cuts. This is mainly true for East Germany (65\% losers) where long-term unemployed with a substantial employment record in the GDR and subsequent receipt of higher unemployment assistance are now transferred to flat-rate UB II (Becker/Hauser 2006, Blos/Rudolph 2005, see figures 1 and 2). 
Figure 1: Change in Benefit Levels due to Hartz IV Reform, Former Unemployment Assistance Recipients, by Household Type

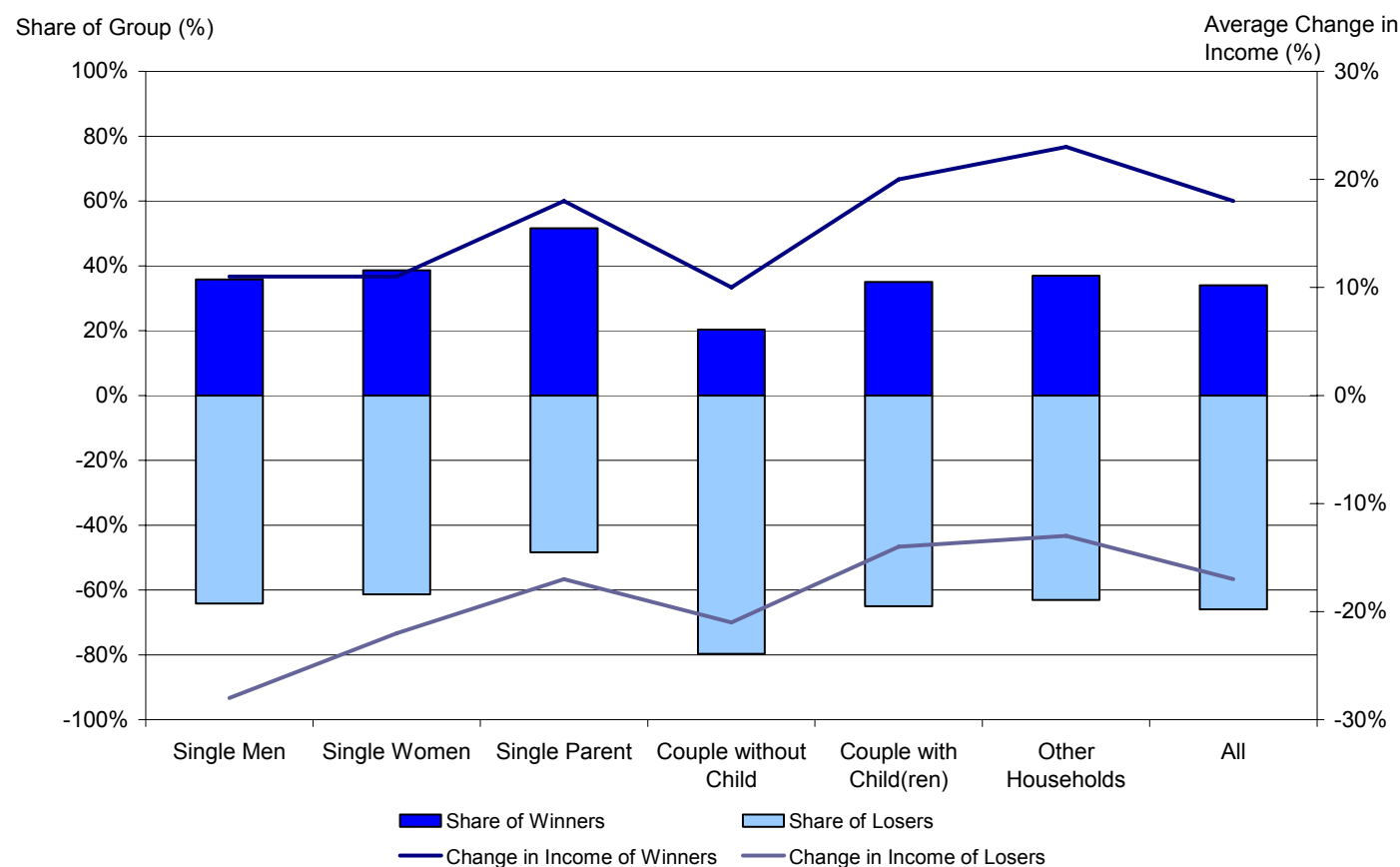

Source: Becker/Hauser 2006.

Figure 2: Change in Benefit Levels due to Hartz IV Reform, Former Unemployment Assistance Recipients, by Age Group

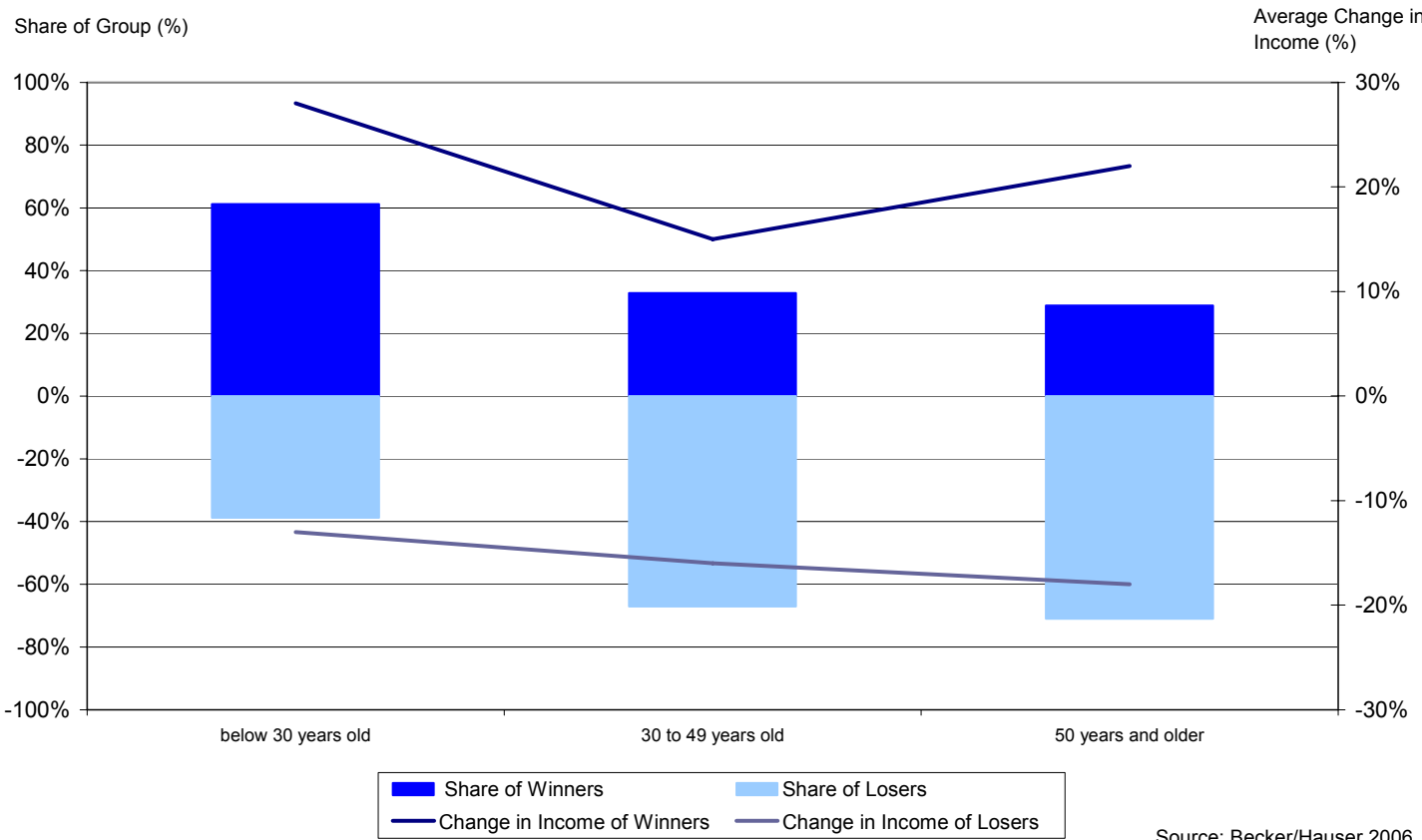

Basic income can also be received in all cases of need where resources from work and other income are not sufficient to pass the threshold income set by law. Hence, basic income support does not only focus on registered unemployed without entitlements to unemployment insurance 
benefits, but also on people in school and training or in dependent employment if they pass the means-test. The same holds for self-employed. In contrast to former social assistance, UB II recipients are covered by both statutory health insurance and old-age pension insurance which also means that self-employed can receive health insurance coverage at a low premium under UB II.

Although the legislator defined the prerequisite for UB II receipt - capability of working - in a legally unequivocal manner, two problematic issues have been quick to emerge: For one thing, unequivocal assignment is not a question of law; rather, whether a person can work for at least three hours daily is a factual problem that is certain to raise dispute. The term "capable of working" is a criterion of delimitation vis-à-vis social assistance, since only persons capable of gainful employment can be expected to earn their living consistently and primarily through their own work. Consequently, there is a need for the various benefit institutions to reach a uniform decision on this issue. The essential aim of consistently placing persons able to work for at least three hours a day and also members of their Bedarfsgemeinschaft under a single regime (either SGB II or SGB XII) has been judicially confirmed, and the relevant decisions have found approval in the literature (SG (Social Court) Oldenburg, ruling of $10 \mathrm{Jan}$. 2005 - S 2 SO 3/05 ER, annotated by Berlit (2005); SG Oldenburg, ruling of 18 Jan. 2005 - S 46 AS 24/05 ER, annotated by Luthe (2005).

In January 2005, more than 90 percent of former social assistance have been assessed as "capable of working" and consequently transferred from municipal responsibility to the new basic income support scheme financed out of taxes at the Federal level. However, first analyses by the BA regarding the structure of long-term unemployed recipients of UB II show that about half of all UB II beneficiaries have a considerable distance to the labour market. This holds in particular for long-term unemployed without vocational training, over 50 years of age, with severe health problems or a migration background especially in regions with high unemployment. About 400.000 to 600.000 people assessed as capable of working obviously have severe barriers to labour market integration.

Eligibility criteria are detailed in $\S 10 \mathrm{SGB}$ II and regulate what kind of work jobseekers can reject without risking curtailment of UB II. In princi- 
ple, the person capable of working, but in need of assistance can reasonably be expected to accept any kind of work. Nevertheless, there are exemptions designed to ensure the regulation's due conformity with basic rights. Thus a job is unreasonable if the jobseeker is mentally or emotionally not in a position to perform the specific work, or if performance of the work would substantially impede the future pursuit of his or her previous vocation. Moreover, priority is given to the raising of the jobseeker's own child or the partner's child. The care of a child who has reached the age of three is, as a rule, ensured in a day-care facility or in some other way, and is thus to be worked towards by the competent local authorities. The same applies to the care of dependants. Besides that, an omnibus clause comes to bear if some other important ground prevents the performance of the work in question.

The construct of the eligibility rule is important for understanding the new concept of placing demands on the recipients of basic security for jobseekers. Other than in the case of unemployment assistance, this regulation has deliberately been decoupled from the eligibility criteria under $\S 121 \mathrm{SGB}$ III. The legislator justifies this by pointing out that demands on basic security recipients must be more stringent than those adopted in the insurance system because the burden on the general public resulting from the neediness of individual persons must be kept as low as possible.

In sum, the grounds of unreasonable hardship under § 10 SGB II are much more narrowly defined than those under the Third Book of the Social Code (SGB III) and, in part, have even been tightened vis-à-vis antecedent regulations on social assistance. At present, there is no evidence to suggest that established administrative practice or court rulings undermine the activating function of strict eligibility rules.

\subsection{The Personal Integration Agreement}

The results from an individual profiling process at the employment offices are set out in a binding integration agreement. This written agreement states both the services that will be provided to the job seeker as well as the job seeker's obligation regarding job search activities and programme participation, where required. An unemployed individual will be threatened by sanctions if he or she deviates from the integration agreement or does not cooperate appropriately. 
Integration agreements pursuant to $\S 35(4)$ SGB III for UB I recipients are not a precondition for participating in active measures. Rather they are regarded as an instrument for improving the placement procedure. Under the insurance scheme integration agreements have a limited significance. They are linked only to active measures, but not to passive benefit receipt. The agreement therefore cannot be used to sanction unemployed persons. As a consequence, integration agreements are scarcely applied within the legal ambit of SGB III. The agreement's mere restriction to the acquisition of more comprehensive information for the unilateral decision on active employment promotion measures fails to do adequate justice to the potential inherent in agreed strategies. In contrast to integration agreements for UB II claimants, the merits of negotiated strategies under the insurance scheme mainly lie in the psychological sphere.

In contrast to the insurance scheme personal agreements for UB II claimants are mandatory pursuant to $\S \S 2(1)$ sent. 2 and 15 SGB II. The two parts have to conclude an integration agreement stipulating the necessary services and obligations. This duty is not a duty in the legal sense, but a so-called incidental obligation, meaning its fulfilment is not legally enforceable. But it is indirectly "compelled" via the imposition of a financial sanction. Jobseekers face financial disadvantages if they refuse to enter into an integration agreement ( $\$ 31(1)$ SGB II).

\subsection{Sanctions}

According to $\S 144$ SGB III benefit receipt could be suspended temporarily if a UB I recipient

- refuses suitable work or a suitable activation measure

- resigns work without good reason or

- shows insufficient effort to look for a new job

- Fails to notify in the case of dismissal to the employment office.

The sanction consists in the imposition of a disqualification period of normally 12 weeks.

A key element has been introduced through a reversal of the onus of proof in respect of the "good reason" which can justify a disqualification period. Now it is the unemployed person who must prove the facts within his or her sphere of activity and scope of responsibility - and not the administra- 
tive authority, who only bears the burden of proof under the general rules of evidence.

In contrast to unemployment insurance, however, basic income support (UB II) cannot be suspended completely in case of lack of willingness to work or to participate in reintegration programs, but only reduced to a certain extent as minimum resources needed for physical existence cannot be withdrawn even if the behaviour of the recipient violates general principles of activation. In extreme cases, benefits in kind can replace cash benefits.

The sanction regulation under $\S 31(1)$ sent. 1 no. 1c SGB II implies that the duty to take up reasonable work is not a legal duty, but a mere incidental obligation. This is because the regulation makes clear that work need not actually be taken up for the receipt of benefits under SGB II, but that the refusal to accept reasonable work only has financial consequences for the jobseeker. The subsequent provisions of § 31 SGB II moreover do not entail a complete denial of all benefits under SGB II in case of the beneficiary's persisting unwillingness to work, but instead specify the sanctions to be adopted.

The possible curtailment of UB II and its ultimate withdrawal as provided under § 31 SGB II, constitute important enforcement measures. UB II recipients are obliged to accept any offer to suitable work. The definition of suitable work was broadened. Both the beneficiary's refusal to conclude an integration agreement and his or her non-compliance with agreed duties, but also the rejection of a reasonable job offer, an immediate offer or a public employment opportunity without a valid reason lead to a 30 percent reduction of benefits (standard rate) upon first breach of duty. A second breach of duty incurs a 60 percent reduction, followed by the complete withdrawal of benefit if a renewed breach occurs within a year. To ensure the constitutionally guaranteed subsistence minimum, the provision of inkind benefits is left to the duty-bound discretion of the institution granting basic security - §31(3) SGB II (Wunder/Diehm 2006). These refined sanctioning provisions addressing UB II claimants are a result of legal fine-tuning effective as of August 2006 or January 2007 after an unexpected increase in numbers of beneficiaries. This also led to stricter sanctioning clauses for beneficiaries under 25 that stipulated that after the first 
incidence of misconduct, benefits can be restricted to benefits in kind. However, the duration of sanctions can be reduced from 12 to 6 weeks.

\subsection{Activation Measures for UB I recipients}

Active employment promotion include a variety of measures stipulated under $\S 3(1)$ SGB III. Examples of active employment measures are: counselling and career guidance, job placement, job creation schemes, wage subsidies, training measures to improve integration prospects, and the defrayal of retraining costs during participation in further vocational training.

In the early days of labour market policies, as expressed in the Federal Employment Promotion Act (Arbeitsförderungsgesetz) of 1969, not only the unemployed but also persons with insufficient training were entitled to long-range training measures, receiving generous support during these measures and even for six months afterwards if they did not immediately find a job. Thus, active labour market policies offered possibilities of upgrading the labour force, both to the benefit of the individual (upwards mobility) and the collective (maintaining a well-trained labour force). Soon after the first labour market crisis in the mid-1970s, the entitlements of the individuals to training measures - and to the accompanying payments- were severely curtailed.

With the Hartz reforms a number of new instruments were created that aim at a more effective re-integration of the unemployed although they are not "activating" in a narrow sense, i.e. used to enforce benefit conditionality. These innovative instruments comprise different forms of flexible and subsidized employment apart from "classical" employer-oriented wage subsidies:

1. temporary agency work for the unemployment provided by specific agencies associated with the PES (Personal-Service-Agenturen),

2. part-time work up to EUR 400 per month exempt from employees' contributions to social insurance and taxes (Minijobs) replacing older models of minor employment (geringfügige Beschäftigung) with a lower earnings threshold,

3. jobs between EUR 400 and 800 per month with employees' social insurance contributions increasing proportionally with earnings (Midijobs), 
4. start-up grants for small business providing subsidies for up to three years (Ich-AG or "Me Inc.").

Additionally, preventive measures like "job-to-job placement" have been enforced. Pursuant to §37b SGB III, persons whose employment or training relationship is due to end are obliged to report personally as jobseekers to the local employment office no later than three months prior to the termination of that relationship. Non-compliance with this reporting obligation entails a disqualification period of one week. It is hoped that early reporting will permit the Employment Agencies to become active faster and thus more successfully, than in the past. The financial loss set by law for late reporting has met opposition and has therefore become a matter for the courts. ${ }^{7}$ In the last instance, the Federal Social Court (Bundessozialgericht) came to the conclusion that unemployment insurance benefits could only be reduced on account of belated reporting if the jobseeker was to blame for this.

\subsection{Activation Measures for UB I I recipients}

The provision of services is based on individual need for assistance. UB II recipients are no longer excluded from most of the instruments of ALMP provided by SGB III. The implementing institutions (Arbeitsgemeinschaften, ARGEn, or Optionskommunen, municipalities) are in principle entitled, as set forth in $\S 16(1)$ SGB II, to apply all the instruments available for UB I recipients by reference to the relevant provisions of SGB III. Moreover, SGB II has introduced additional measures which have been designed specifically for welfare recipients and their particular barriers to employment like debt, abuse of alcohol or other drugs, socio-psychological counselling and child care services stipulated in $\S 16(2)$ SGB II or a startup allowance pursuant to $\S 29 \mathrm{SGB}$ II. The promotion of re-integration measures is regulated in $\S 14$ SGB II, meaning the institutions responsible for providing basic security to jobseekers primarily become active with the aim of reintegrating needy persons capable of working into the labour market.

7 Despite the meanwhile mitigated version of the sanction regulation, court rulings remain relevant: BSG (Federal Social Court), judgment of 25 May 2005, SGB 2006, 49 ff.; BSG, judgment of 18 Aug. 2005. 
In a recent amendment by 20 July 2006, § 15a SGB II now provides that persons capable of working who within the past two years have not received cash benefits under either SGB II or SGB III are immediately to be offered benefits for integration into work upon applying for benefits pursuant to SGB II. This "immediate offer" of integration services is to avoid the need of assistance or at least prevent long spells of such need and to test the applicant's readiness to accept employment.

If needy persons capable of working find no job, public employment opportunities are to be created on their behalf (§ 16(3) SGB II). Prerequisites governing the admissibility of job opportunities are not to be discussed further here. Important, rather, is how the legislator's conceptions are put into practice.

The legislative intent was that the provision of time-limited job opportunities (so-called "One-Euro-Jobs") would avoid the emergence of a subsidized, state-financed "third" labour market, as was the case with the largely unsuccessful public job creation measures in the 1990s. Activation programs should be applied only if they avoid, eliminate, shorten or reduce benefit dependency through integration into a regular job.

Integration benefits come under the reservation of $\S 3$ SGB II, which permits them only if they are required to avoid or eliminate, shorten or reduce the need of assistance for integration (into the primary labour market). The activating effect of job opportunities is seen in re-accustoming jobless persons to activities with a steady work rhythm, punctuality, and so forth, and, hence, to improve their integration prospects ("workpedagogic objective") (Bieritz-Harder 2005). The foremost aim is always to achieve integration into the regular labour market, possibly also to regain fully-fledged employment in the wake of such job opportunities. The approach of regarding these additional jobs as a quid pro quo for the receipt of Unemployment Benefit II does not conform to the enacted text, nor can this be inferred from the judgments so far delivered in respect of $\S 16(3)$ SGB II.

\section{Constitutional Constraints to Activation}

From a legal point of view there are three problem areas concerning activation policy. The one involves the "constitutional guarantee of a subsis- 
tence minimum". The second problem concerns the "constitutional guarantee of property" concerning insurance benefit claims and the third one "workfare" (public work) as a possible infringement of the "constitutional guarantee of occupational freedom".

\subsection{Constitutional Guarantee of a Subsistence Minimum}

Basic income support refers to Art. 1. (1) GG Abs. 1 on "human dignity" and to the "social state principle" (Sozialstaatsprinzip) of Germany as mentioned in Art. 20(1) GG and Art. 28(1) GG. In contrast to other constitutions in Europe, the German Basic Law (Grundgesetz, GG) does not proclaim fundamental social rights, nor does it lay down programmatic social guidelines. The "social state principle", however, comprises duties and mandates for state action only when legal, political and/or societal reality diverges on too great a scale from constitutional objectives.

The "constitutional guarantee of a subsistence minimum" seems to be the lynchpin for the admissibility of employment promotion benefits and for the provision of basic security to jobseekers or, alternatively, for the possibility of reducing these benefits as a sanction.

To date, the Federal Constitutional Court as court of last instance has delivered no decision on the interpretation of the Basic Law in this question. Yet a number of its decisions seem to imply that the right to human dignity in conjunction with the social state principle establishes a positive duty of the state to secure minimum conditions for a life worthy of human beings, thus correlating with a negative duty to prevent state intervention in the subsistence minimum.

Originally, this duty took the form of police measures on behalf of indigent persons, notably to avoid any breach of the peace (Zacher 2004). In the 1970s, the Federal Constitutional Court finally acknowledged the duty of the state to secure "minimum conditions for a dignified existence" (BVerfGE 40, 121 (133); 45, 187 (228). However, the Federal Constitutional Court made clear that the stipulation of an amount in figures representing the positive duty of the legislator to deliver benefits could not be inferred from the constitution. Consequently, the Federal Social Court ruled on 23 November 2006 that the level of UB II conforms with constitu- 
tional requirements as parliament has ample room to define a concrete monetary amount (BSG Judgment, AZ B 11b AS 1/06 R).

Hence, neither the state guarantees regarding "human dignity" nor the "social state principle" provide the basis for a definition of the level of basic income support as a minimum level of resources (soziokulturelles Existenzminimum) needed in order to safeguard existence and participation in society It is the responsibility of parliament to define this standard in accordance with constitutional principles. This refers to the principle of "demanding" (Fordern) stipulated in § 2 SGB II. Need for help is defined in $\S 9 \mathrm{SGB}$ II and is only given if life cannot be sustained by individual effort and resources, in particular if there is not sufficient income from suitable jobs.

Not to be forgotten in the discourse over the "amount of subsistence minimum" is the fact that assistance-induced social stigmatisation and social exclusion against the background of hidden poverty can weigh more heavily than any increase in financial assistance granted. Precisely the aspect that a dignified life without work can be financed through state support, but that the aim of helping people to help themselves might then be neglected, should be included in the further discussion on activating measures.

As the social state principle also implies the concept of the social state founded on the basic rights of freedom (freiheitlicher Sozialstaat) the state holds no "monopoly on social affairs". Hence, the social state principle epitomises the "basic formula of self-responsibility", which also underlies all activating measures of employment promotion.

\subsection{The Property Guarantee}

Claims to unemployment benefit are protected against interventions in existing positions through the guarantee of property (BVerfGE 72, $9 \mathrm{ff}$;; 74, 9 ff.; 74, 203 ff.; 92, 365 ff., see also Papier (2003)). Concerned are claims which have been acquired through employee and employer contributions and which serve to secure existence on account of their function as wage replacement benefits. Amendments of law are thus admissible either if they leave vested legal positions unaffected, i.e. apply only to the future, or if they are cushioned with the help of transitional provisions. The legislator must submit grounds to legitimate any intervention. 
Moreover, positions protected as property rights can be modified by way of admissible provisions governing their content and limits - Art 14(1) sent. 2 GG. This means in particular, grounds of public interest with due regard for the principle of proportionality can justify an intervention in a safeguarded position. Regarding the cut in maximum benefit duration of UB I from 32 to 18 months for older workers, conformity to constitutional requirements is safeguarded as a sufficient transition period between legal changes in 2003 and effective application on newly unemployed in early 2006 elapsed. Cuts in benefit duration in unemployment insurance are possible to the extent that the principle of protection of confidence for a limited period of time for both the insured and the current beneficiaries is observed.

From these arguments it may be inferred that basic security benefits do not come under the property guarantee of Art. 14 GG. They are not based on substantial personal contributions because they are granted from tax revenues in the form of welfare benefits, irrespective of any previously paid contributions. This was confirmed by the most recent judgment of the Federal Social Court. It was made clear that earnings-related unemployment assistance could be replaced by flat-rate UB II. As both benefits are means-tested and tax-funded, the property guarantee of social insurance does not apply.

\subsection{Constitutional Guarantee of Free Choice of Occupation}

Regarding activating labour market policies, one might raise the question whether demanding participation in community work ("workfare") is feasible given the constitutional requirements.

Under Art. 12(1) GG, all Germans have the right to freely choose their occupation or profession, their place of work, and their place of training. Important here is that Art. 12(1) GG is a purely defensive right, and not a right to any financial security on behalf of negative occupational freedom. Persons who freely decide never to work enjoy the constitutional protection of this freedom, but are not entitled to demand money from the state to enable them to live a life without working. This means that the linking of state financial assistance in the event of unemployment to the basic 
willingness to accept reasonable employment is not inherently an infringement of Art. 12(1) GG.

Also to be noted in this connection is Art. 12(2) GG, whereby no one may be required to perform work of a particular kind except within the framework of a traditional duty of community service that applies generally and equally to all. Moreover, forced labour may be imposed only on persons deprived of their liberty by a court judgment (Art. 12(3) GG). To date, encroachments on these rights through SGB III and SGB II regulations have been denied on the grounds that, in light of the historical origin of this provision, only forced labour in the sense of a direct coercive measure is prohibited. Measures with an (indirect) coercive character, such as the suspension, reduction or stop of financial benefits upon rejection of a reasonable employment offer, are not open to question as long as the security system of social assistance ensures that the essential means of subsistence are guaranteed (Gagel 2005).

The subject matter of judicial decisions was whether the proposition of a job opportunity constitutes an administrative act and, hence, can be deemed an independent regulation that could be contested by jobseekers through a protest procedure and subsequent legal action. The decisions rendered to date have denied these effects of the proposition. The courts have in this way conceded greater leeway to the Employment Agencies, instructing jobseekers to first await a sanction notice, which will only be issued if they refuse to accept the proposed job opportunity. Only following this notice must the legality of the proposition be reviewed on the basis of the prerequisites set out in § 16(3) SGB II SG (Social Court) Hamburg, ruling of 7 J une 2005 - S 62 AS 434/05 ER; SG Berlin, ruling of 18 July 2005 - S 37 AS 4801/05 ER).

In general, the provisions of SGB II regarding the obligation to accept a One Euro J ob if integration into the regular labour market is not possible in the foreseeable future do not contradict the principle of free choice of occupation or profession The main objective of this intervention is not forced labour but helping benefit recipients reenter (or at least prepare them for) the labour market so that need can be terminated (Sachverständigenrat 2006). 
A possible infringement of contractual freedom protected under Art. 2(1) GG could be derived by the duty to conclude a personal integration agreement. However, the conclusion of the agreement is only indirectly "compelled" via the imposition of a financial sanction, so that there is no direct obligation to contract and no direct intervention in the jobseeker's contractual freedom. Court decisions delivered to date have been geared to the lack of a direct coercive measure and therefore deny any infringement of a basic right.

\section{Governance and I mplementation}

\subsection{Distribution of Competences}

The Federal Employment Agency (Bundesagentur für Arbeit) as unemployment insurance agency is responsible for UB I payment as well as for the implementation of active labour market policy laid down in the Third Book of the Social Code (SGB III). The BA is a corporation under public law ( $\S 367(1)$ SGB III). The Bundesagentur für Arbeit is not only responsible for unemployment insurance but also for the implementation of active labour market policy laid down in the Third Book of the Social Code (SGB III).

Whereas the institutions of the social insurance are in principle administered as federal corporations under public law (Art. 87(2) GG), the distribution of competence for basic income support of jobseekers (Grundsicherung) is less clear. It was disputed for a long time. The optional assignment of competence to the local authorities is the result of negotiations between the Federal and the Länder governments.

Basic income for needy jobseekers ensues from the concurrent legislative power in respect of "public welfare" under Art. 74(1) no. 7 GG. In the case of persons "capable of working", this basic security for jobseekers supersedes both the public welfare benefit of unemployment assistance and that of social assistance. The uniform federal regulation is deemed necessary both for the establishment of equal living conditions and for the maintenance of legal and economic unity.

The obligatory establishment of joint offices (ARGEn) under § 44b SGB II is highly problematical from a constitutional point of view. It involves a form of mixed administration that is not admissible. This poses a threat to 
the principles governing the autonomous performance of functions and the clear assignment of responsibility.

\subsection{Changes in the Organizational Setting}

The Hartz reforms changed the general framework in which the delivery of employment services operates. Hartz III (2004) and Hartz IV (2005) entailed big changes in the realm of employment services. In the past and especially after the already mentioned "placement scandal" the PES (Bundesagentur für Arbeit, BA) were blamed for operating inefficiently and customer-unfriendly. The aim of Hartz III was therefore to improve the performance by streamlining public employment services. At the beginning of 2004, changes concerning the organisational structure of the BA became effective (Hartz III).

But nearly simultaneously - with the merger of unemployment and social assistance schemes - an external reorganisation of employment services took place. Joint agencies combining former local PES and municipal social assistance (Arbeitsgemeinschaften, ARGEn) for recipients of the basic income support were set up by Hartz IV in 2005.

The parallel internal and external re-organisation of employment services created a more fragmented structure. Instead of implementing one-stopshops for all jobseekers - an explicit objective of the Hartz commission - a two-tier or even three-tier system was created: 178 local PES agencies are responsible for the short-term unemployed and 356 ARGEn for the long-term unemployed and other claimants of the basic security benefit. The institutional setting is even more complicated by considering the 19 districts where the long-term unemployed are dealt with separately by municipalities and local PES offices and 69 municipalities (Optionskommunen) which could opt out for taking over the re-integration of the new UB II benefit recipients without PES participation. This new structure of administrative bodies - a result of protracted federal negotiations - created serious governance problems.

\subsection{BA J obcenters for the Short-term Unemployed}

The local PES offices are foremost responsible for the unemployment insurance benefit (UB I) recipients. Within this regime the Federal Employment Service - the Bundesagentur für Arbeit (BA) - has a unified structure 
with the three main services - placement, active labour market policy and unemployment insurance benefit (UB I) payments - being steered by one public body with administrative autonomy. UB I is mainly financed by compulsory social insurance contributions which are raised from dependent employment covered by unemployment insurance and formally divided in paritarian manner between employers and employees. The unemployment insurance is a self-governing para-fiscal agency with codetermination rights by the social partners. Although contributions and benefits are defined by legislation, it has far reaching autonomy concerning the regulation of implementation. The proper provision of labour market programmes, however, was always conducted by third parties, mostly by non-profit third sector organisations and - to a minor extend - by forprofit organisations. Most recent reforms have withdrawn the influence of the social partners with respect to the regulation of labour market services. Since 2003 tripartite codetermination of the BA is limited to the administrative council, which only has a controlling function, while the executive committee is set up limited in time.

The Bundesagentur für Arbeit was modernised along the lines of the New Public Management. In accordance with a goal-oriented labour market policy, the former management-by-directives approach has been replaced by a management-by-objectives approach. Now quantitative goals are set for each local office taking into account the special circumstances in their local labour market. The formerly hierarchically organised employment offices were converted into customer- oriented job centres (Kundenzentren).

The main objectives of the new BA are the effective and efficient use of the measures provided by the Third Book of the Social Code (SGB III) as well as transparency about how and with which results unemployment insurance funds are spent. Cost-effectiveness in the specific context of each regional labour office is the key criteria when choosing programme contents and participants. Improved targeting of active measures and the allocation of measures and resources opened up a wider scope for fitting clients to measures more individually. Provision of services has been decentralised with the aim of bringing BA activities closer to the specific, individual needs of the clients of the BA. The caseload of advisers is to be reduced and every jobseeker is assigned to a fix caseworker. The use of market mechanisms by outsourcing placement services to external pro- 
viders through placement vouchers or via subsidised temporary work (PSA) has been implemented as a complementary option to improve efficiency and effectiveness of core employment services (Konle-Seidl 2005a).

Profiling of jobseekers constitutes an essential element in the BA reform process. It has been applied since 2005. Beyond the diagnostic function profiling in the German PES serves as a tool for customer segmentation and the determination of individual assistance and - last but not least - as an instrument for the allocation of resources. The unemployed jobseekers are segmented into four categories:

1. "market clients", considered to be job ready and to have the highest chances of finding employment,

2. "clients for counselling and activation" range second and mainly need to be activated in their job search or minor adjustments of skills through short training,

3. "clients for counselling and qualification" need more attention and will likely to be assigned to training programmes and other measures to increase mobility or flexibility,

4. "intensive assistance clients" require special attention since they face the lowest chances of re-employment and are at risk of becoming long-term unemployed.

The assignment to one of the four categories determines the future treatment. Based on the individual profiling result tailor-made action programs (Handlungsprogramme) for each client group are developed. The action programs determine resource allocation. Personal resources and active measures should be allocated in an effective and efficient way. Six different action programmes have been developed:

- quick and sustainable placement for group (1),

- change of perspective for group (2),

- reduction of employment barriers

- and qualification measures for group (3),

- preservation of marketability and

- case management for group (4).

At the end of the intake interview caseworker and jobseeker agree on an action plan specifying individual "integration objectives" and resources. 
Within the comprehensive scientific evaluation of the Hartz reforms on behalf of the government, the preliminary results of Hartz III focuses on the effectiveness of placement services after the (still ongoing) reorganisation of the local employment offices. The study by WZB/infas using a conditional Difference-in Difference-analysis exploits the fact that the new customer-oriented one-stop centres have been introduced at different points in time. Employment service offices that have already transformed into one-stop-centres are matched to agencies that have not. Data is used from the inflow into unemployment of the respective agencies. The results indicate positive effects of customer-centres on the integration into regular employment, though the effects are not significant. This might be due to the fact that the number of agencies used in the analysis is small and the observation period at the present time is a maximum of nine months. In 2007 the final evaluation results based on a longer observation period will be presented (Bundesregierung 2006).

Beyond the econometric measured effects on the individual reintegration chances the monitoring results from the BA controlling system provide information on the achievement of the Agency's operational goals. Although there are no studies available on causal efficiency gains from the BA reform there are hints that the strict outcome oriented performance management shows after two years of fundamental and ongoing reforms already some positive results. The number of unemployment insurance benefit recipients (UB I) decreased in 2005 by six percent compared to the previous year. The transition rate from unemployment to employment (promoted by active measures as well as "just" by placement without extra financial resources) could be improved by 12 percent. Especially the increased number of job-to-job integrations and the early intervention measures to avoid long-term unemployment contributed to a lower stock of UB I recipients in 2005 (Bundesagentur für Arbeit 2006a).

Consequently the "penalty tax" to be paid by the Agency if being unable to integrate its clients into work during the regular UB I entitlement period, was by 30 percent lower than expected. However, the most visible success seems to be the spectacular cost reduction and the expected surplus of EUR 10 billions in 2006. For more than one decade the financial balance of the contribution based receipts and expenditures of the BA was deficient. The Agency itself assessed that efficiency gains from the BA reform 
contributed to one third, extra effects and the positive influence of an improved business cycle for two thirds to the surplus (Bundesagentur für Arbeit 2006a).

However, there are also critical assessments deriving from the success oriented overall strategy of the BA concerning the treatment of different client groups. The strict orientation of the management towards effectiveness and efficiency aims at achieving net effects just of the insurance based resources. The new concept regarding the allocation of resources between client groups concentrates the Agency's resources and activities on the "clients for counselling" who, though not easy to find jobs for, still have a fair chance, in the short term, of being integrated into the labour market.

This change might, however, run the risk of disadvantaging the "intensive assistance clients" who have very poor chances of finding a job as such people will benefit less frequently from active labour market measures. Expensive and long lasting programmes for the intensive assistance clients may in the Agency's management logic not pay off. Moreover, in the cost-benefit logic the "penalty tax" worsens further the treatment perspectives for the hard-to-place client group. While participating in longlasting programmes a transition for intensive assistance clients into employment before exhausting the UB I claim ( 12 or 18 months for $55+$ ) is rather unlikely the Agency has to pay additionally to the programme costs the "penalty tax". As a consequence, the incentives for the BA to "park" the hard-to-place clients are strong. But more than to blame the Agency for neglecting the fulfilment of social tasks it is the institutional setting of the German unemployment regime - contribution based UB I and tax financed UB II administered by different institutions - which generates a trade-off between the fulfilment of social and efficiency tasks (KonleSeidl/Schewe 2007).

\subsection{ARGE J obcenters and Municipal Agencies for the Long-term Unemployed}

The original idea to create joint customer centres which was supposed to end the different treatment of recipients of unemployment insurance benefits and unemployment assistance (dealt with by BA) on the one hand and social assistance on the other hand (administered by the municipali- 
ties) did not work for political reasons. A major goal of combining UA and SA benefits in one single means-tested income replacement schemes for persons who are able to work was therefore to reduce the administrative overhead inherent in the old system and to arrive at more coherent activation strategies for all persons on welfare benefits that are able to work. However, financing and decision powers with respect to employment policies remain dispersed in important respects.

The introduction of Unemployment Benefit II in 2005 was combined with the creation of joint bodies of BA and the municipalities - the ARGE consortia - that are now in charge of administrating ALG II and designing employment services for benefit recipients in all districts except for regions where the municipalities opted for taking over the complete responsibility and for the districts with continued division of responsibilities.

But despite the joint framework, the financial responsibilities as well as the decision powers within the ARGEn are divided. The local authorities are responsible for reimbursement of accommodation, heating and onetime costs for e.g. initial furnishing and clothes, child care services, as well as debt, drug and socio-psychological counselling according $\S 16$ (2) sent. 1 SGB II. The BA agencies are responsible for the payment of UB II as well as for all activation measures (SGB III and SGB II). Funding for these services is provided out of the federal budget. Additionally, about 30 percent of the housing and heating costs are also financed out of the federal budget.

Whereas the federal burden of funding of ALG II, related employment services and housing costs for the federal government went up, municipal responsibility with respect to the implementation of labour market policy increased. The municipalities can free-ride in their decisions at the expense of the state budget. As the municipalities maintain the financial responsibility for income support for persons who are not able to work (social assistance), the municipalities have an incentive to shift costs by classifying persons as being able to work who would otherwise obtain municipal social assistance. Indeed, in 2005 more than 90 percent of the former SA recipients were assessed to be "capable of working" and therefore transferred to the federal funded ALG II system. 
From unclear regulation of organisational competences concerning organizational procedures arise a lot of administration problems within the ARGEn. Also the staff of the ARGEn remains employed by different public sector entities - the Federal Labour Office and the respective municipality - with differing contractual employment conditions such as working time and salaries. This has lead to frictions in the administration of the ARGEn. Difficulties in harmonising activation targets across regions became apparent when the municipalities complained that the Federal Labour Office would hamper efficient job placement by centralistic ordinances. In response, an agreement was made in October 2005 between the federal government, the BA and the municipalities that leave the determination of operational targets for the ARGE to their governing council. However, the agreement could not solve so far the fundamental governance problems often described as "clash of cultures" between a more centralistic BA staff and the municipal staff used to decide on a greater discretional leeway.

The fact that derives from the division of responsibilities between national and local governments is one reason for increased compensation by the federal government because of benefit over-run for the ALG II scheme. The in-congruency between spending and decision powers at the different layers of government inhibits a more efficient management of employment policies for the long-term unemployed. With the "option clause" available until 2010, 69 municipalities have been given temporarily exclusive competence for administering the new system, the segmentation of employment services was further aggravated (Konle-Seidl 2005b).

A comparative quasi-experimental evaluation of the two different implementation systems required by federal law is under way. The evaluation results will partly determine the further assignment of employment services to the municipalities or a strengthening of decision rights of the $B A$ within the ARGE. Nevertheless, if responsibilities for UB II related policies are assigned to municipalities this should be accompanied by a financing mechanism providing incentives for the municipalities to engage in efficient job placement. 
Table 3: Institutional Responsibilities

\begin{tabular}{|l|l|l|}
\hline Regime & Unemployment Insurance & Basic Income Support \\
\hline Regulation & $\begin{array}{l}\text { Third Book of the Social Secu- } \\
\text { rity Code (SGB III) }\end{array}$ & $\begin{array}{l}\text { Second Book of the Social } \\
\text { Security Code (SGB II) }\end{array}$ \\
\hline Target groups & Short-term unemployed & $\begin{array}{l}\text { Needy persons capable of } \\
\text { working; partners and de- } \\
\text { pendants }\end{array}$ \\
\hline Bunding & $\begin{array}{l}\text { Unemployment Insurance Bene- } \\
\text { fit (UB I) }\end{array}$ & $\begin{array}{l}\text { Basic Income (UB II and } \\
\text { Sozialgeld) }\end{array}$ \\
\hline $\begin{array}{l}\text { Compulsory social insurance } \\
\text { contributions and deficit cover- } \\
\text { age by Federal government }\end{array}$ & $\begin{array}{l}\text { General taxes at Federal } \\
\text { level (income support and } \\
\text { activation measures and } \\
\text { part of housing and heating } \\
\text { costs) and municipalities } \\
\text { (2/3 of housing and heating } \\
\text { costs) }\end{array}$ \\
\hline Administration & $\begin{array}{l}\text { Bundesagentur für Arbeit (BA); } \\
\text { regional and local employment } \\
\text { offices }\end{array}$ & $\begin{array}{l}\text { ARGE jobcentres (joint } \\
\text { bodies by BA and munici- } \\
\text { palities), municipalities opt- } \\
\text { ing out (Optionskommu- } \\
\text { nen) or divided structures }\end{array}$ \\
\hline
\end{tabular}

\subsection{I mplementation}

The binding element between legal provisions concerning activation policy and the effects of such a policy on an individual level is the implementation by local agencies. Concerning the demanding part of activation, this means foremost stricter monitoring of job search efforts and programme participation and the practice in imposing sanctions in case of an infringement of the rules.

The Hartz reforms tightened benefit conditionality with respect to availability for work and program participation and introduced more flexibility regarding sanctioning. The objective of a stricter regulation rests on the fact that hardly any sanctions were imposed under the former law or were not asserted with the necessary intensity. Although sanctioning via temporary suspension of UB payments was in principle possible already in the past, available information indicates that until the recent reforms counsellors of the local employment offices rarely decided to impose sanctions, and the sanctions advocated were often not executed (Wilke 2003).

More recently, the rate of sanctioning has slightly increased, but the dispersion in the application of sanctions between local employment offices appears to have been large and to have increased as well 
(Oschmiansky/Müller 2005). This means that despite the fact that legal aspects allow in principle no margin of discretion in practice there is a "though" and "soft" interpretation of legal provisions by employment offices.

Table 4 shows that the sanction rate for UB I recipients has slightly increased between 2004 and 2005. In general, however, sanction intensity is still rather low in Germany.

Table 4: Sanction Rates in Unemployment Insurance (UB I)

\begin{tabular}{|l|l|l|}
\hline & $\mathbf{2 0 0 4}^{2}$ & $\mathbf{2 0 0 5 ^ { 2 }}$ \\
\hline $\begin{array}{l}\text { Sanctions } \\
\text { ance benefit recipients (a) }\end{array}$ & 168.293 & 150.887 \\
\hline $\begin{array}{l}\text { Specific sanctions for missing early registra- } \\
\text { tion requirement and job search interviews } \\
\text { (Meldeversäumnis) (b) }\end{array}$ & n. a. & 110.247 \\
\hline \multicolumn{2}{|l|}{} \\
\hline As a percentage of sanctions (a) & \multicolumn{2}{l|}{261.134} \\
\hline Voluntary quits & 6.7 & 7.6 \\
\hline Refusal of suitable job offer & 2.7 & $2.0^{3}$ \\
\hline Refusal of participation in ALMP scheme & 3.1 & 2.4 \\
\hline Quit of ALMP & 2.0 & 1.3 \\
\hline $\begin{array}{l}\text { As a percentage of the total inflow of unem- } \\
\text { ployment insurance benefit recipients }\end{array}$ & $\mathbf{9 \%}$ & $\mathbf{1 0 \%}$ \\
\hline
\end{tabular}

1 On average $6 \%$ of all imposed sanctions (benefit stops) were lifted after successful legal action.

2 Figure covers seven months only (May - December). ${ }^{3}$ Includes in 2005 for the first time (4.100) cases of sanctioning for insufficient job search.

Source: Bundesagentur für Arbeit.

Data on sanctions according to $\S 31$ SGB II for UB II recipients are not available yet. An internal audit report in nine ARGEn, however, came to the conclusion that just in 21 percent of all cases of obvious noncompliance sanctions were imposed. In a recent review the Federal Audit Office complained among the most serious deficits implementing the new system that benefits for the long-term unemployed were paid without sufficient monitoring of eligibility; that intake interviews took place too late, that in half of the proofed cases personal integration agreements were not concluded and that activation proposals were not pursued seriously in 4 out of 10 cases and finally that in six out of ten cases non-compliance of rules was not sanctioned (Bundesrechnungshof 2006). 
Critics were also raised about the requirement of "public interest" concerning public work. "One Euro Jobs" are a good example to demonstrate the still insufficient implementation of the Fördern und Fordern principles of activation. On the one hand these jobs have been designed to promote the employability of unemployed persons with a bad prognosis for a quick integration into the regular labour market. On the other hand these jobs serve as a work-test for individuals with good chances but low search efforts. At the same time, earning an additional EUR 1.00 to 1.50 for every hour worked in public employment for six to nine months at 30 hours a week while full benefit receipt is continued may reduce search intensity and lead to a certain lock-in effect (Cichorek/Koch/Walwei 2005).

Results from a survey of case managers carried out in fall 2005 show that One Euro Jobs are partially implemented as a work-test, however in most cases One Euro J obs are offered on a voluntary basis, i.e. on a consensual basis. Case managers see their prime objective in re-establishing or stabilizing employability and in strengthening societal integration through structuring daily life, improved self-confidence and additional resources for dept redemption. Immediate reintegration into the labour market is not a principle objective of this scheme (Wolff/Hohmeyer 2006).

One Euro Jobs are by far the most frequently used activation scheme in SGB II active labour market policy (figure 3). In fall 2006 about 15 percent of all UB II recipients participated in active schemes, approximately half of them in One Euro Jobs. 
Figure 3: Activating Interventions under SGB II

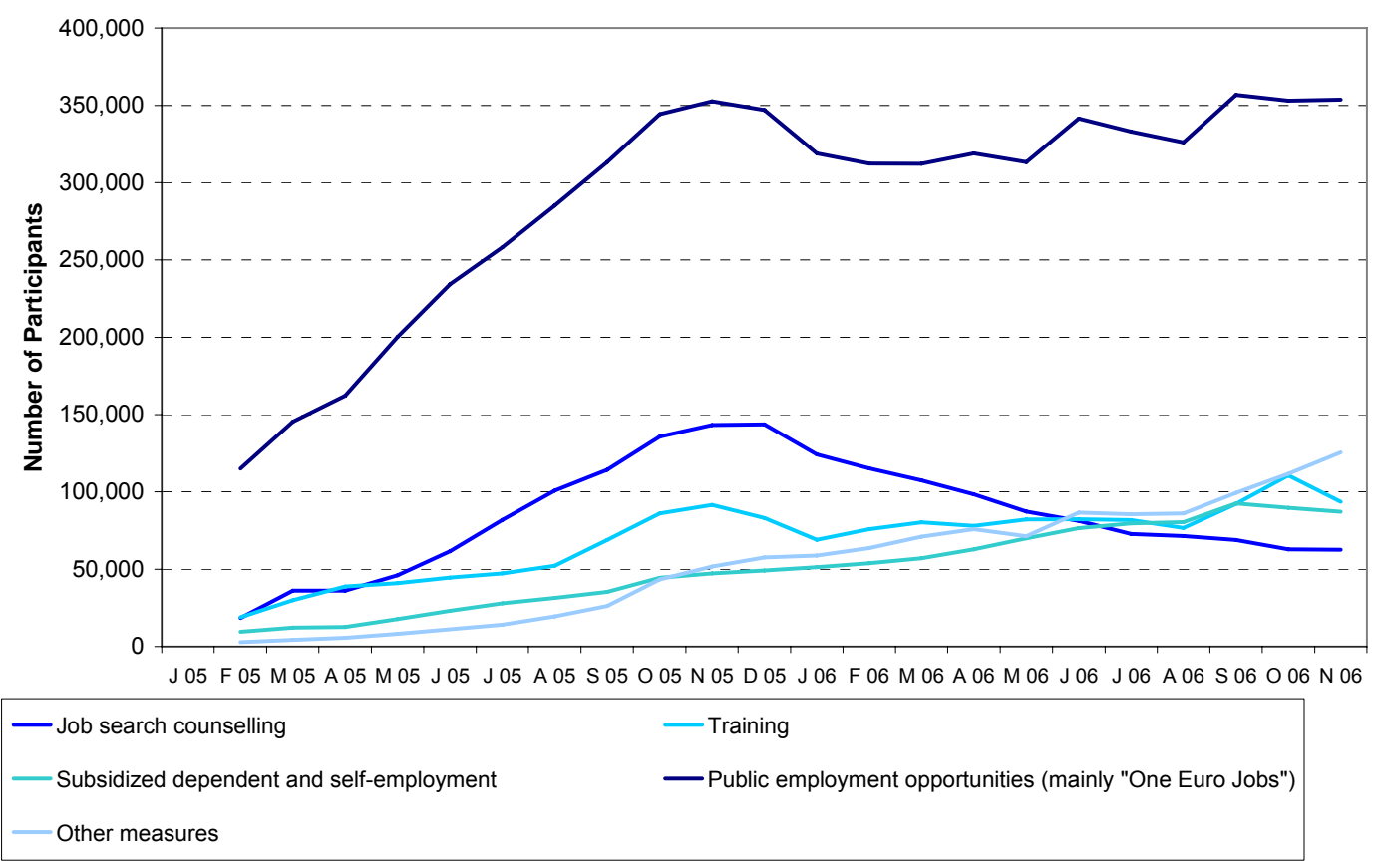

Although more staff was assigned to local ARGE offices in order to reach a workload of one caseworker responsible for 75 clients, the actual workload is still much higher - especially for UB II recipients older than 25 ( 1 to 200) whereas the average workload with respect to young people ( 1 to 77) nearly met the fixed target in 2005 already (Bundesagentur für Arbeit 2005).

However, there is - up to now - not more than anecdotal evidence concerning the real service delivery process and the transactions between caseworkers and clients at the front-line. Little is known about keeping the promise to provide modern tailor-made services according to the individual needs of their clients. Little is also known about the view of personal advisers on their role under an activation regime. They normally see themselves as helping professionals and not to as government agents aiming at altering the personal behaviour of their clients. Advisers and case-managers are convinced that due to the high long-term unemployment there are very limited job opportunities on the regular labour market for their clientele. Stricter monitoring of availability criteria and job search as well as sanctioning in case of non-compliance is therefore perceived as not very helpful. In this context the availability of One Euro Jobs is a very useful tool for advisers to provide time-limited job opportunities for the large group of hard-to-place UB II recipients. 
The possible failure to fully implement reforms on the frontline has also implications for equity in service provision. One aim of the SGB II is to give more discretion to local employment offices and to provide more cooperative instruments in order to permit necessary adjustments to the individual case and simultaneously handing back unemployed individuals the necessary responsibility for their lives. The strong codification (Verrechtlichung) of the status of individuals under German employment promotion law (SGB III) was often deplored and assessed as stabilizing a status quo that is more or less resistant to reform. However, strong fears are raised that the way in which the new system is configured, i.e. providing less enforceable claims and judicial controls of the labour administration imply a weaker legal position with a weakening of the position of individuals. However, the greater degree of flexibility of activation at the local level does not mean that UB II beneficiaries do not have access to legal advice or the right to file a lawsuit.

\section{Outcomes of Activation: A Preliminary Assessment}

It is also much too early to assess the effects of the policy shift towards activation on employment, unemployment or distributional outcomes with empirical data. At this stage, there are no empirical studies on the microlevel regarding changes in the duration of unemployment spells, the return to employment, the quality of subsequent employment and the effects of activating interventions. The same holds for potential explanations of developments on the macro-level except for a study that shows an increase in matching efficiency due to the Hartz reforms (Fahr/Sunde 2006).

At this point in time only a preliminary empirical assessment is possible. However, causal statements can hardly be made. In addition, some findings can be based on simulation studies and on comparisons between benefit levels and equivalent market wages.

\subsection{Open Unemployment}

The peak in registered unemployment in early 2005 with more than five millions unemployed, an all-time high, is largely due the combination of seasonal effects and the statistical effect of (capable of working) former social assistance recipients and their partners being registered as unem- 
ployed for the first time after Hartz IV came into force. This explains an increase in unemployment of about 350.000 to 400.000 . In that sense, Hartz IV contributed to more open unemployment by providing greater transparency in German labour market statistics as former social assistance recipients capable of working are now more "visible". At the same time, hidden unemployment decreased so that broad unemployment remained stable (Konle-Seidl/Lang 2006, see table 5).

Table 5: Broad unemployment in Germany (1.000 persons)

\begin{tabular}{|l|l|l|l|}
\hline & $\mathbf{1 9 9 8}$ & $\mathbf{2 0 0 4}$ & $\mathbf{2 0 0 5}$ \\
\hline Registered unemployment & 4.281 & 4.381 & 4.754 \\
\hline $\begin{array}{l}\text { Participants in active labour market } \\
\text { schemes }\end{array}$ & 695 & 845 & 768 \\
\hline Public job creation (SGB III) & 269 & 180 & 67 \\
\hline Public employment opportunities (SGB II) & 0 & 16 & 126 \\
\hline Hidden labour force (Stille Reserve) & 1.244 & 1.068 & 758 \\
\hline Total & 6.489 & 6.490 & 6.473 \\
\hline
\end{tabular}

Note: medium projection for 2005. Source: BA and IAB; Konle-Seidl/Lang 2006.

The recent decline in registered unemployment to less than 4 millions in November 2006, however, can in part be explained by a positive economic environment. There may be some motivation effect of Hartz IV on the unemployed in the sense that the eventual transfer to means-tested and flat-rate UB II increases search intensity and reduces reservation wages during the receipt of UB I. However, there is no systematic evidence on this so far.

\subsection{Benefit Receipt}

On the other hand, recent data on the number of beneficiaries show that there is a divergent development of transfer receipt in UB I and UB II. While figures of UB I receipt, i.e. short-term unemployment, decline, the number of UB II beneficiaries has increased considerable over the last 24 months. This means that the coverage of the unemployed by insurance benefits declines whereas reliance on basic income becomes more important. The relation is now approximately four fifths on UB II and one fifth on UB I (figure 4). Hence, basic income is of growing relevance regarding the structure of benefits in the German welfare state. Compared to unemployment insurance benefits, means-tested basic income is now the more 
important welfare scheme. However, most recent figures also show some decline in UB II.

Figure 4: Recipients of Unemployment Benefits I and II, 2004-2006

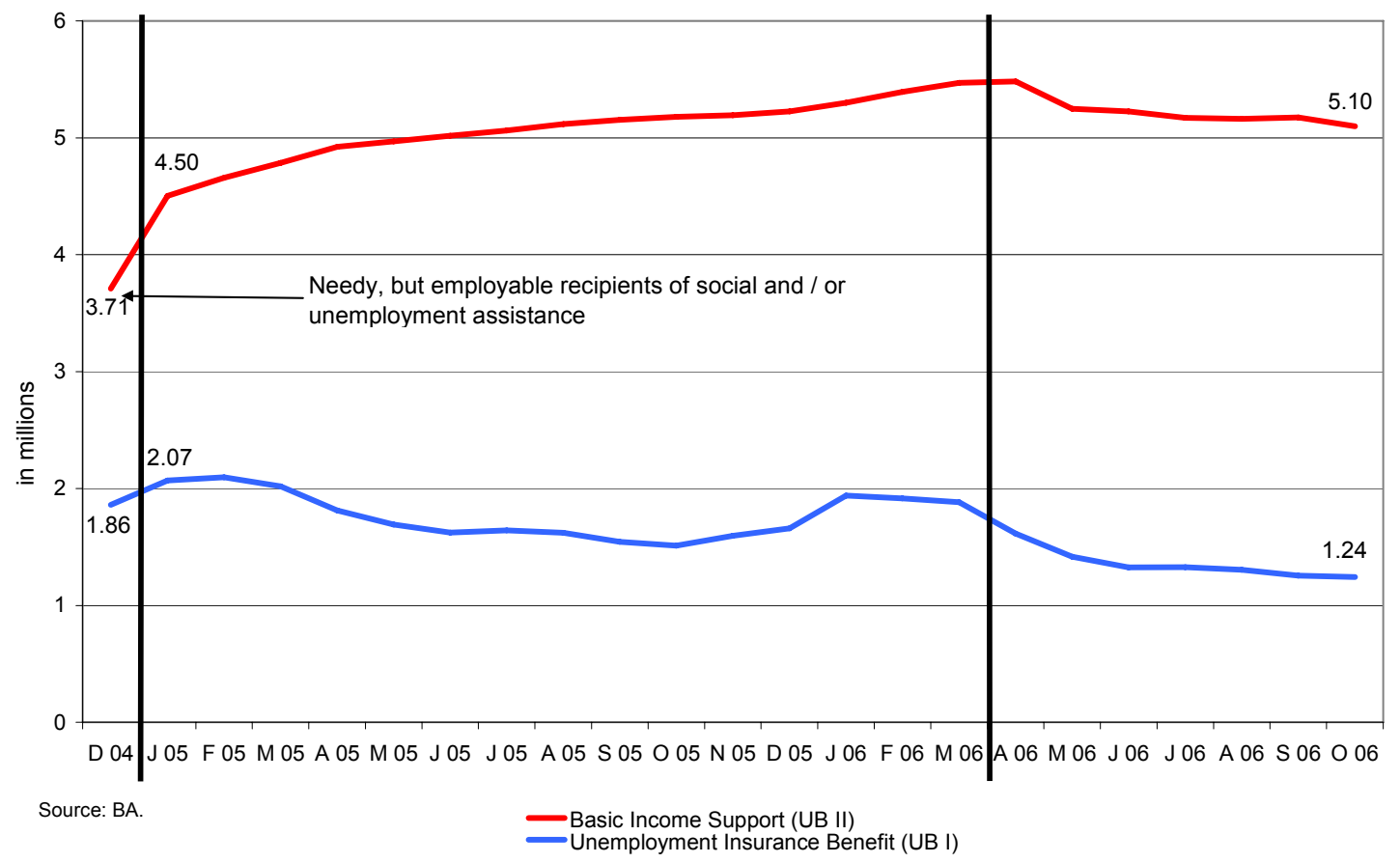

While the number of UB II beneficiaries increased strongly, data on individual benefit spells in 2005 shows that there is considerable mobility in and out of UB II (Graf/Rudolph 2006). About 74 percent of all households in need in January 2005 depended on benefits throughout the year while 26 percent could leave UB II. Households entering UB II later in 2005 had a higher chance of leaving basic income support within 12 months (43 percent). Continued benefit dependency over twelve months was most frequent with lone parents who could opt for an exemption from the job search requirement.

\subsection{Earnings}

However, UB II is not only received by long-term unemployed, but also by people entering the labour force and by employees or self-employed without sufficient earnings to pass the threshold of guaranteed basic income. In this respect it is most notable to see that about one million of all UB II recipients have income from earnings, i.e. about one fifth of all UB II beneficiaries are employed on either low hours or low wages (Bundesagentur für Arbeit 2006b). Only a smaller share of UB II recipients works full-time (see figures 5 and 6). But due to current earnings disregard 
clauses, there are strong incentives to work part-time and top-up low earnings from low hours by UB II (Aufstocker). Through this arrangement, UB beneficiaries can earn EUR 160 on top of their benefit through parttime work, in particular with the Minijob arrangement that provides for flexible jobs with an earnings ceiling of EUR 400 per month exempt from employees' social insurance contributions and taxes. This concerns about 500.000 people. They can hardly improve their net income by moving to longer working hours as additional earnings lead to benefit withdrawal. Hence, Hartz IV provides for a general und unlimited in-work benefit and strong part-time incentives. This also means that benefit recipients are relatively indifferent when faced with wage cuts imposed by employers in sectors not covered by collective agreements.

Figure 5: Earnings Combined with UB II Receipt, September 2005

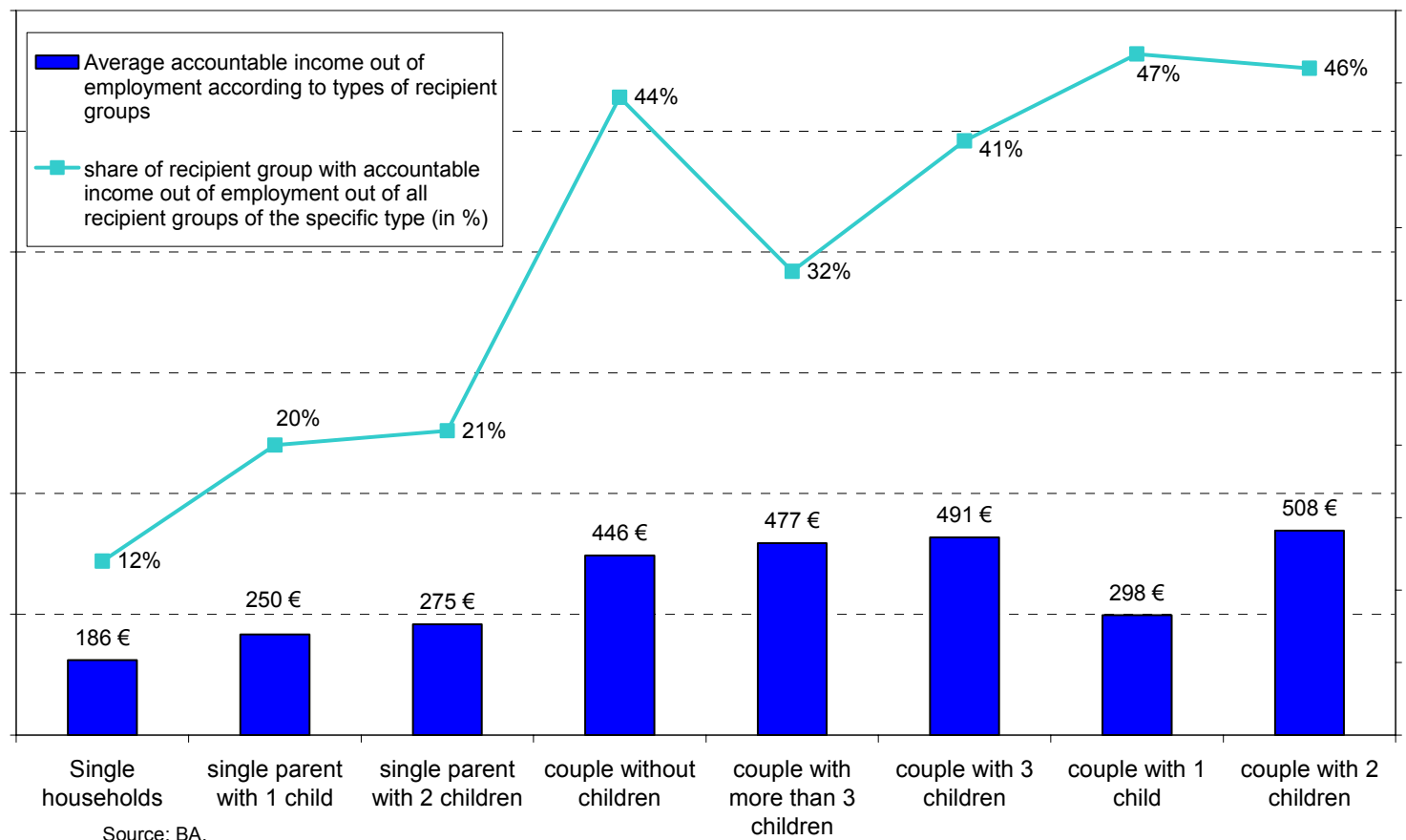
Source: BA. 
Figure 6: Distribution of UB II Recipients' Income from Work, September 2005

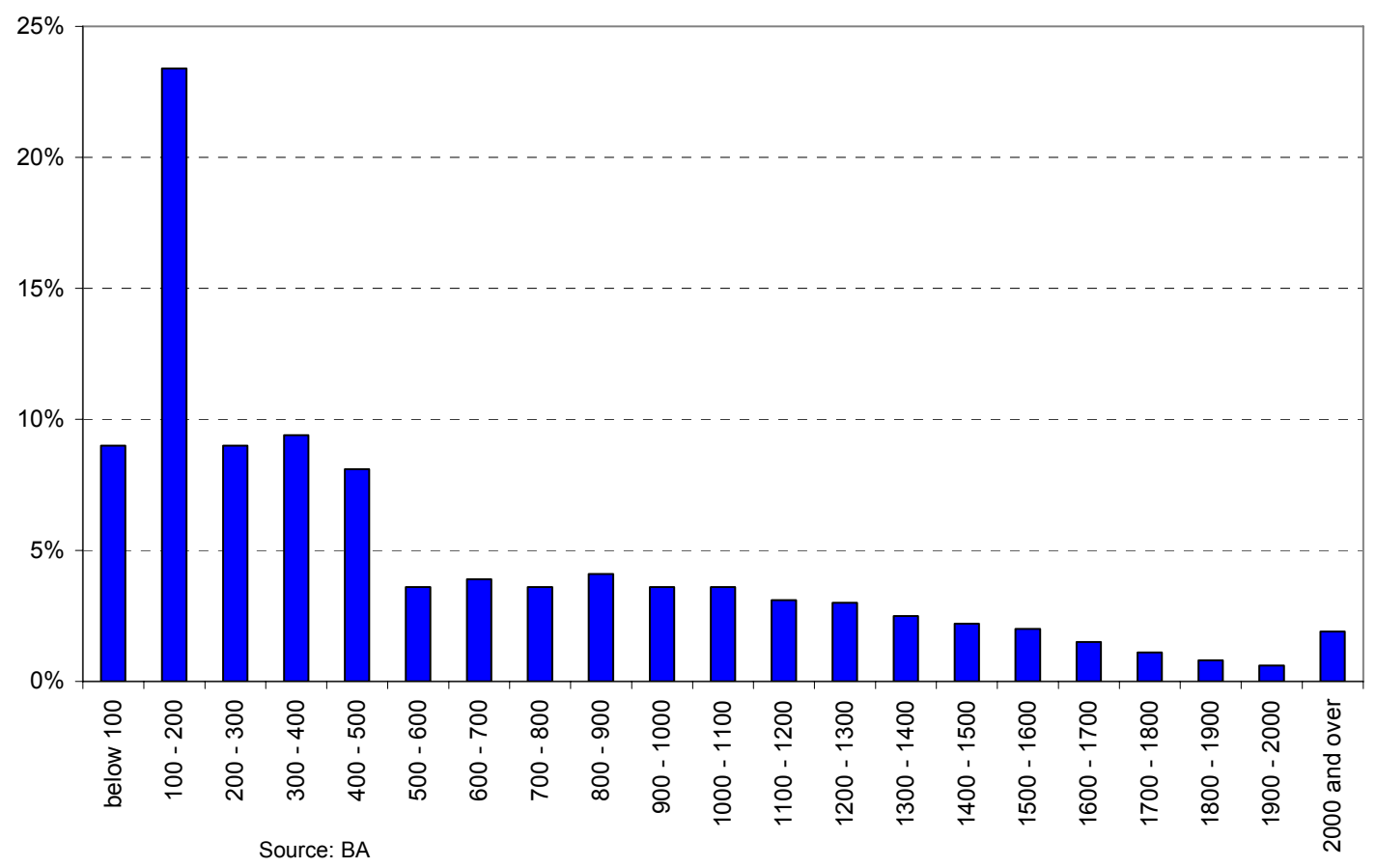

The part-time incentive is particularly relevant with respect to needy households with dependent children where realistic equivalent market wages to be earned when moving from long-term unemployment to regular jobs with low qualification requirements in the private service sector are close or even inferior to the benefit level (Boss/Christensen/Schrader 2005, Brenke 2006, Cichorek/Koch/Walwei 2005, see table 6). Employment disincentives are more significant in these cases, and part-time work will provide for an additional earnings top-up. This does not only hold for earnings from regular part-time but also for One Euro Jobs that provide approximately EUR 1.00 to 1.50 per hour in addition to full benefits. 
Table 6: Benefit Levels and Equivalent Market Wages

\begin{tabular}{|c|c|c|c|c|c|c|}
\hline & \multirow{2}{*}{$\begin{array}{l}\text { Net benefits from } \\
\text { UB II + social al- } \\
\text { lowance for de- } \\
\text { pendents + hous- } \\
\text { ing/heating bene- } \\
\text { fit (+ temporary } \\
\text { supplement) }\end{array}$} & \multicolumn{2}{|c|}{$\begin{array}{c}\text { equivalent } \\
\text { wages }\end{array}$} & \multirow{2}{*}{$\begin{array}{c}\text { UB II } \\
+ \text { compensa- } \\
\text { tion for pub- } \\
\text { lic employ- } \\
\text { ment oppor- } \\
\text { tunity of } € \\
1.50 \text { at } 30 \mathrm{~h} \\
\text { per week }\end{array}$} & \multicolumn{2}{|c|}{ equivalent wages } \\
\hline & & $\begin{array}{c}\text { net } \\
\text { hourly } \\
\text { wage } \\
(40 \text { h per } \\
\text { week) }\end{array}$ & $\begin{array}{c}\text { gross } \\
\text { hourly } \\
\text { wage } \\
\text { (40 } \\
\text { h per } \\
\text { week) }\end{array}$ & & $\begin{array}{c}\text { net hourly } \\
\text { wage (40 h } \\
\text { per week) }\end{array}$ & $\begin{array}{c}\text { gross hourly } \\
\text { wage (40 h } \\
\text { per week) }\end{array}$ \\
\hline & \multicolumn{6}{|c|}{ in EUR per month } \\
\hline Single & $662-822$ & $\begin{array}{c}3.10- \\
4.40\end{array}$ & $\begin{array}{c}3.70- \\
5.65\end{array}$ & $857-1017$ & $\begin{array}{c}4.70- \\
5.90\end{array}$ & $6.10-8.10$ \\
\hline $\begin{array}{l}\text { Single par- } \\
\text { ent, one } \\
\text { child }\end{array}$ & $1090-1310$ & $\begin{array}{c}3.35- \\
4.95\end{array}$ & $\begin{array}{c}4.20- \\
6.30\end{array}$ & $1285-1505$ & $\begin{array}{c}4.75- \\
7.00\end{array}$ & $5.95-9.95$ \\
\hline $\begin{array}{l}\text { Married, } \\
\text { single } \\
\text { earner }\end{array}$ & $1034-1354$ & $\begin{array}{l}5.65- \\
7.80\end{array}$ & $\begin{array}{c}7.10- \\
9.80\end{array}$ & $1229-1549$ & $\begin{array}{l}7.10- \\
8.95\end{array}$ & $8.90-11.50$ \\
\hline $\begin{array}{l}\text { Married, } \\
\text { single } \\
\text { earner, two } \\
\text { children }\end{array}$ & $1574-2014$ & $\begin{array}{l}3.80- \\
7.35\end{array}$ & $\begin{array}{c}4.80- \\
9.25\end{array}$ & $1769-2209$ & $\begin{array}{c}5.30- \\
8.55\end{array}$ & $6.35-10.90$ \\
\hline
\end{tabular}

Net hourly wages include child benefit, child supplement for low-wage earners and housing benefit. Source: IAB (Cichorek/Koch/Walwei 2005).

\subsection{Public Expenditure}

Regarding public expenditures, the implementation of Hartz IV in 2005 led to higher rather than lower public expenditure and to an increase rather than a decline in the number of benefit recipients as compared to 2004 . This has to do not only with incorrect prior estimations (due to unreliable statistics) but also with some legal provisions that allow for individual benefit receipt by young unemployed, migrants and fake single households, but also to the unintended emergence of a broad in-work benefit scheme. For 2006, planned expenditures amount to EUR 47 billions (figure 7). However, actual expenditure might reach about EUR 50 billions which is approximately EUR 10 billions more that expected at the outset. At the same time, however, unemployment insurance will run a surplus of about EUR 10 billions. Expenditure increases in UB II and related active labour market policies reflects the shift from unemployment insurance to basic income which also means a shift from contribution-based to tax-funded passive and active labour market policy schemes (Kaltenborn/Schiwarov 2006a, 2006, Kaltenborn/Knerr/Schiwarov 2006). 
Figure 7: Expenditure for Active and Passive Labour Market Policies in Assistance Schemes before and after the Reform

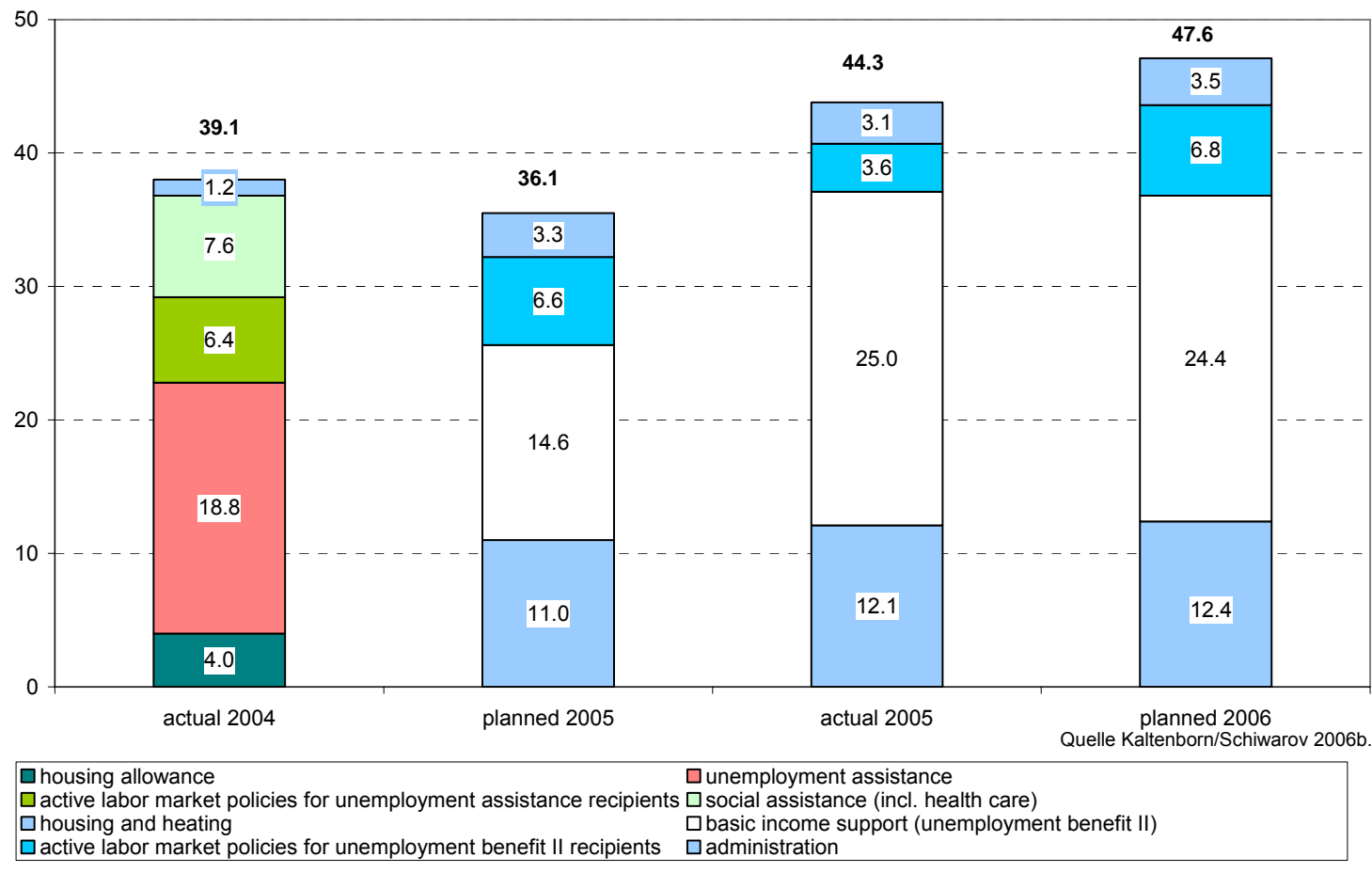

\subsection{Poverty}

There is no information so far on the effects of the shift towards activation in Germany on unemployment duration or on stability and quality of subsequent employment. The same holds empirical evidence driven impact on wage dispersion and inequality before and after taxes and benefits. This will only become available later. However, simulation studies (Becker/ Hauser 2006 see figure 8) point at a slight increase in poverty due to Hartz IV although this studies do not take into account potential dynamic effects on reemployment. As with changes in benefit generosity, the effect on poverty is assumed to be most pronounced in East Germany. 
Figure 8: Poverty Before and After Hartz IV

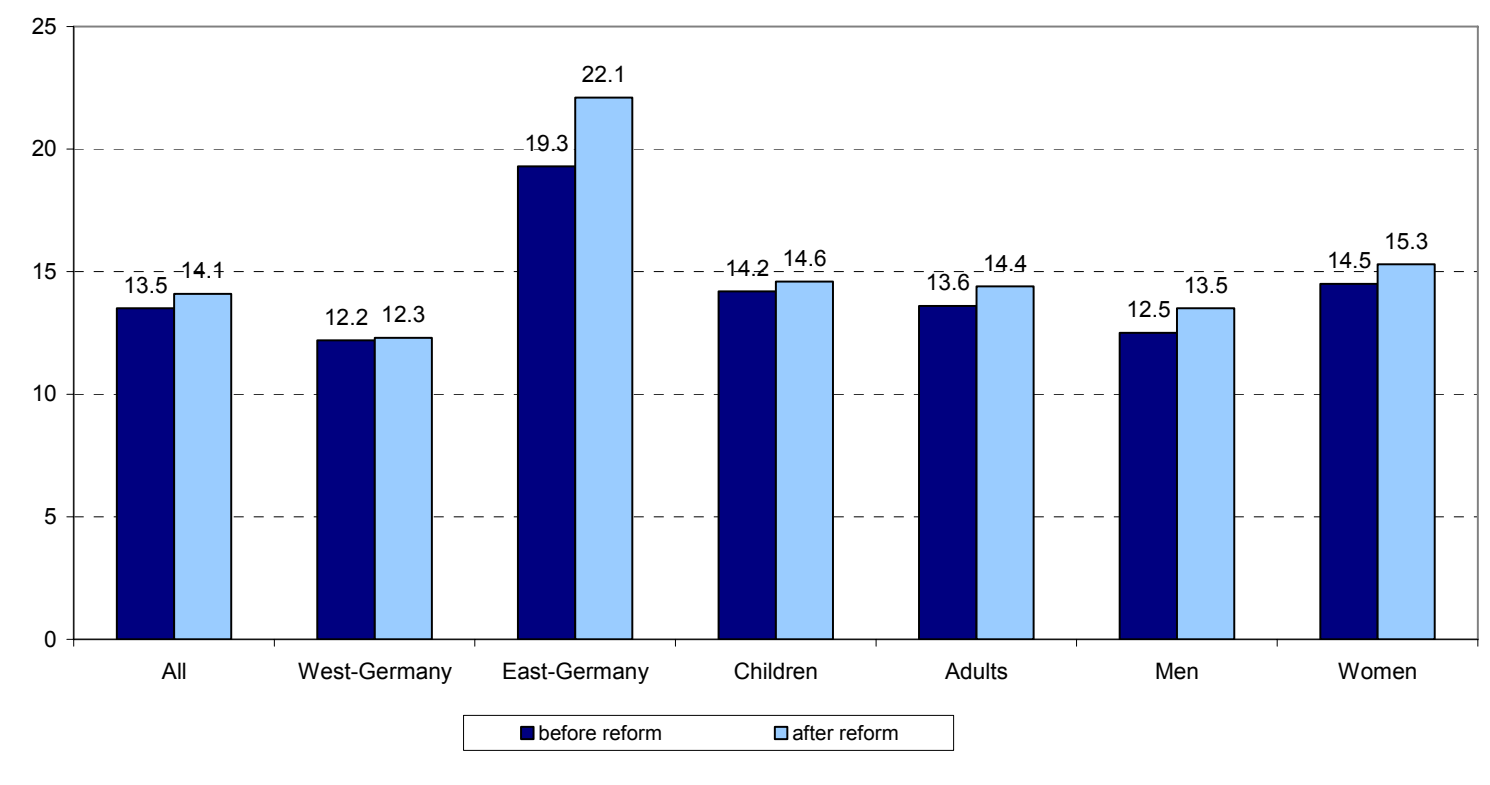

Poverty level: 60\% of median; new OECD-Scale; Simulation with EVS 2003 (First term).

\subsection{Overall Assessment}

Although it is rather early for a preliminary assessment of the outcomes of the shift towards activation in Germany, empirical information available so far suggests at a differentiated judgment. On the one hand, empirical evidence shows a remarkable shift to a more goal- and efficiency-oriented approach within contribution-based active schemes administered by BA. Interim results on the evaluation of BA reorganization also show positive results (Bundesregierung 2006) as do empirical studies on matching efficiency (Fahr/Sunde 2006), yet some of the evaluation studies on specific active labour market programs within unemployment insurance are a bit inconclusive (Bundesregierung 2006, Jacobi/Kluve 2006). Stronger profiling and goal-orientation in the assignment of active schemes to shortterm unemployed helps explain the savings in contribution-based active and passive labour market policies even though actual sanctioning is moderate.

The situation is different, however, with respect to activation of the longterm unemployment under SGB II, i.e. recipients of UB II. Effects on benefit levels are highly differentiated with respect to household composition and prior earnings. Yet, there has not been a bold cut in benefit generosity, but even some expansion. At the same time, current benefits are equal or even superior to equivalent market wages for people with a low 
earnings potential in the private sector. In such a system, activation crucially depends on frontline implementation of demanding and enabling schemes and the actual application of benefit conditionality. But anecdotal evidence and some partial empirical data suggest a moderate approach towards activation in actual practice, i.e. regarding use of integration agreements, work test or sanctions.

The moderate level of activation in practice may be explained by several factors: disincentives embodied in the existing funding and governance arrangements in particular with regard to effective activation of potential long-term unemployed; a high level of legal codification which, together with a lack of a coherent normative framework and ambiguous institutional incentives, may lead to reluctant implementation in local agencies and by frontline staff. In addition, the perceived, but also actual lack of jobs for the low-skilled may hamper activation through job offers and inhibit entry into gainful employment.

This is not only to be explained by weak labour demand due to unfavourable business cycle conditions in 2005 and early 2006, i.e. until recently, but also by institutional preconditions limiting labour market flexibility and wage dispersion while at same time creating strong incentives to combine benefit receipt with partial labour market attachment only. The difficulty of entering the German labour market is largely due to the fact that policies create specific compartments or segments of low-wage and flexible employment such as benefit top-up/Minijobs, subsidized employment and One Euro Jobs with transitions to higher wages or more stable employment being rather problematic.

A partial liberalization in dismissal protection, the easing of restrictions on temporary agency work and product market regulations such as the lifting of the requirement of a master craftman's diploma (Meisterbrief) in some crafts sectors was certainly not sufficient in this respect (Eichhorst/Kaiser 2006). It was not possible to implement more far-reaching reforms that could stimulate labour demand and increase the supply of entry-level jobs.

\section{Summary and Outlook}

Germany embarked on the shift towards activation much later that its European neighbours, but this policy change was in many respects more 
fundamental and comprehensive as it implied a major break with the welfare state tradition which had been characterized by the social insurance logic of a "Bismarckian" system. Passive, status protecting benefits had been used in the past to buffer economic adjustment. Against this background, policy change from status and occupational orientation in favour of basic income support for the long-term unemployed in combination with stricter formulation and potential enforcement of "sleeping" demanding elements is a major element of "path departure" and recalibration of rights and obligations in the German welfare state. This also implied a major overhaul of active labour market policy schemes and governance. But the shift towards activation is not just a "technical" issue and an example of implementing New Public Management principles in Germany.

The late, but fundamental change in Germany is most notable in comparison with other European countries such as the UK, Denmark, the Netherlands or Sweden as the German approach to activation is relatively broad and ambitious as "capability of working" is defined mainly in a medical sense so that the number of people to be activated is much higher than elsewhere, in particular given the fact that alternative escape routes do not play a prominent role in Germany these days (i.e. disability benefits) or are being closed (e.g. early retirement). This dramatically increases transparency regarding non-employment and lead to high open (registered) unemployment at the beginning of the activation of the long-term unemployed with the Hartz IV reform.

Contrary to widespread perceptions, however, stronger activation is not associated with a general decline in benefit levels - even not for the longterm unemployed - as Hartz IV is not only activation, but also a social policy reform widening access to benefits and assistance. Rather the severance of the link between benefits for the long-term unemployed and prior earnings changed the perception of benefit generosity. This may - in conjunction with more demanding interventions by administrative bodies change job search effort due to increased fears of downward mobility in case of longer unemployment spells (Eichhorst/Sesselmeier 2006).

This has more fundamental consequences as it signals the departure from status protection and a "benevolent" welfare state to a more basic, means-tested system of social protection and stricter "workfare". This is 
not only a result of the abolition of earnings-related unemployment assistance but also due to the associated cut in maximum duration of unemployment insurance benefits for older workers. In empirical terms this becomes evident with respect to the diminishing role of contribution-based and earnings-related unemployment insurance benefits relative to the number of beneficiaries of means-tested basic income schemes.

Basic income for jobseekers, but also means-tested earnings top-up for low-wage earners is now by far the more important benefit scheme than unemployment insurance for short-term unemployed with sufficient prior employment record. This new arrangements questions the status of lifetime achievement and occupational orientation that was characteristic for the German model of industrial production in the past. On the one hand, this may reduce incentives to pursue professional careers as acquired rights in the social insurance system depreciate more quickly than in the past, and after (accelerated) expiry of unemployment insurance benefits, virtually all jobs are suitable. On the other hand, however, reduced benefit generosity in case of long-term unemployment and even the threat of being transferred to means-tested flat-rate basic income may lead to higher individual effort in order not to lose track of the regular labour market and raise individual job search intensity in case of unemployment. This may even have positive effects on human capital investment. Anyway, the reform reinforces individual responsibility and reduces the possibility to rely on status-oriented benefits and human capital enhancing labour market policies.

Given this broad paradigm shift, acceptance deficits come as no surprise. Cuts in UB I duration, replacing earnings-related unemployment assistance with a flat-rate benefit for the long-term unemployed and fears of "enforced" low-wage employment as a result of stricter activation motivated major public unrest before and after the Hartz IV reform came into effect. However, despite a broad public controversy, the long-term implications of this institutional change remain rather implicit. Part of the acceptance deficit can be explained by the lack of a general normative framework developed in order to explain the necessity of these changes and to emphasize the potential of this reform. This may also be partly responsible for reluctant implementation in practice as the implicit norma- 
tive assumptions are not shared by all actors charged with implementation.

The difficulties experienced with the politics and the implementation of activation in Germany points at more fundamental issues as both policy makers and the general public are very reluctant with regard to a complementary liberalization of the labour market and higher wage dispersion which would help strengthen the supply of entry jobs for the activated. The concept of "work first" may be embodied in current German legislation, yet the idea of "any job is better than no job" still raises widespread opposition. Hence, the question whether a higher degree of inequality is inevitable in the general labour market in order to overcome benefit dependency is still unsolved. Being accustomed to a "high equality, low activity" arrangement, activation of the long-term unemployed and the lowskilled implies a major shift of paradigm. However, at the same time, trying to avoid low-wage employment means tacit acceptance not only of inequality, but also poverty outside the labour market and of inequality between core and margin of the labour market.

With regard to foreseeable future, the German activation regime is most probably not a stable one. One more coherent policy solution implying a general lowering of basic income is virtually ruled out, therefore there is no prominent role for strong in-work benefits (see e.g. Sachverständigenrat 2006).

This is also true for a broad flexibilization of the labour market which would be complementary to this approach inspired by the Anglo-Saxon experience. The public and policy makers are highly reserved with regard to these issues. Social justice consideration might rather result in attempts at stabilizing wages through the introduction of a statutory minimum wage even if this might be detrimental to the labour market integration of the long-term unemployed. Policy makers may even try to resort to a more limited definition of "capability of working" and assign part of the hard-to-place to public sector employment.

We would rather expect future steps to fine-tune the system. Short-term fiscal considerations due to the unexpected inflow into the basic income system led to more restrictive eligibility criteria and stricter sanctioning 
provisions as early as in summer 2006. Within the next years we might see some changes regarding targeted in-work benefits, a rather restrictive approach towards part-time incentives in the transfer system and a more general revision of administrative competences and funding which would help strengthen incentives for more efficient activation by BA, ARGEn and municipalities. Together with the relative decline of active schemes in the contribution-based system this may eventually lead to the more flexible repertoire of SGB II to become the relevant set of instruments in German active labour market policies. This may help activation without a formal lowering of social benefits.

\section{References}

Ambs, Friedrich (Ed.) (2005): Gemeinschaftskommentar zum Arbeitsförderungsrecht (GK - SGB III). Neuwied: Luchterhand.

Bandemer, Stephan von/Blanke, Bernhard/Hilbert, J osef/Schmid, Josef (1995): Staatsaufgaben - von der "schleichenden Privatisierung" zum "aktivierenden Staat", in: Behrens, Fritz, et al. (Eds.) (1995): Den Staat neu denken: Reformperspektiven für Landesverwaltungen. Berlin: Edition Sigma, 41-60.

Becker, Irene/Hauser, Richard (2006): Verteilungseffekte der Hartz IVReform: Ergebnisse von Simulationsanalysen. Berlin: Edition Sigma.

Berka, Walter (1996): Bürgerverantwortung im demokratischen Verfassungsstaat. In: VVDStRL 55 (1996), 48-89.

Berlit, Uwe (2006): Das neue Sanktionensystem. In: Zeitschrift für Sozialhilfe und Sozialgesetzbuch 2005, 707-715, 2006, 11-19.

Bertelsmann Stiftung (2001): Kooperation statt Konkurrenz: Studie über die Zusammenarbeit von Arbeits- und Sozialämtern. Gütersloh: Verlag Bertelsmann Stiftung.

Bieback, Karl - Jürgen (2005): Probleme des SGB II: Rechtliche Probleme des Konflikts zwischen Existenzsicherung und Integration in den ersten Arbeitsmarkt. In: Neue Zeitschrift für Sozialrecht, 337-343.

Bieritz-Harder, Renate (2005): Die Arbeitsgelegenheiten des § 16 Abs. 3 Satz 2 SGB II. In: Zeitschrift für Sozialhilfe und Sozialgesetzbuch, 259263.

Blanke, Bernhard (2001): Aktivierender Staat - aktive Bürgergesellschaft: Eine Analyse für das Bundeskanzleramt. Hannover: Universität Hannover. 
Blanke, Bernhard/Koschütze, Albrecht/Lamping, Wolfram (2002): Der aktivierende Staat: Positionen, Begriffe, Strategien. Studie für den Arbeitskreis Bürgergesellschaft und Aktivierender Staat der Friedrich Ebert Stiftung. Bonn: Friedrich Ebert Stiftung.

Blos, Kerstin/Rudolph, Helmut (2005): Simulationsrechnungen zum Arbeitslosengeld II: Verlierer, aber auch Gewinner. IAB Kurzbericht 17/2005. Nürnberg: IAB.

Blüggel, Jens (2005): Die „einheitliche Entscheidung“ der Einigungsstelle nach § 44a SGB II: Zugleich ein Beitrag zur Systemabgrenzung von SGB II und XII. In: Die Sozialgerichtsbarkeit, 377-384.

Boss, Alfred/Christensen, Björn/Schrader, Klaus (2005): Anreizprobleme bei Hartz IV: lieber ALG II statt Arbeit? Kieler Diskussionsbeiträge 421. Kiel: Institut für Weltwirtschaft.

Brenke, Karl (2006): Wachsender Niedriglohnsektor in Deutschland - sind Mindestlöhne sinnvoll? DIW Wochenbericht 15-16/2006. Berlin: DIW.

Bruttel, Oliver/Kemmerling, Achim (2006): New Politics in German Labour Market Policy? The Implications of the Recent Hartz Reforms for the German Welfare State. In: West European Politics, 29 (1), 90-112.

Bundesagentur für Arbeit (2005): SGB II - Sozialgesetzbuch Zweites Buch. Grundsicherung für Arbeitssuchende. Zahlen. Daten. Fakten, Nürnberg: BA.

Bundesagentur für Arbeit (2006a): Arbeitsmarkt 2005. ANBA, Sondernummer, 24. August. Nürnberg: BA.

Bundesagentur für Arbeit (2006b): Grundsicherung für Arbeitsuchende: Anrechenbare Einkommen und Erwerbstätigkeit. Nürnberg: BA.

Bundesrechnungshof (2006): Durchführung der Grundsicherung für Arbeitssuchende - Wesentliche Ergebnisse der Prüfungen im Rechtskreis des SGB II. Bericht an den Haushaltsausschuss und an den Ausschuss für Arbeit und Soziales des Deutschen Bundestages. Bonn.

Bundesregierung (2006): Die Wirksamkeit moderner Dienstleistungen am Arbeitsmarkt. Berlin: BMAS.

Cichorek, Anne/Koch, Susanne/Walwei, Ulrich (2005): Arbeitslosengeld II: Erschweren „Zusatzjobs“ die Aufnahme einer regulären Beschäftigung? IAB Kurzbericht 8/2005. Nürnberg: IAB.

Däggelmann, Günter (2006): Keine stabile Brücke in den ersten Arbeitsmarkt: Erste Erfahrungen der Caritas mit Ein-Euro-Jobs. In: Soziale Sicherheit, 68-71.

Däubler, Wolfgang (2005a): Das Verbot der Ausgrenzung einzelner Bevölkerungsgruppen - Existenzminimum und Arbeitslosengeld II. In: Neue Zeitschrift für Sozialrecht, 225-231. 
Däubler, Wolfgang (2005b): Einmalbedarf und Arbeitslosengeld II: Zur Darlehensregelung des § 23 I SGB II. In: Neue Juristische Wochenschrift, $1545-1547$.

Damkowski, Wulf/Rösener, Anke (2003): Auf dem Weg zum Aktivierenden Staat - Vom Leitbild zum umsetzungsreifen Konzept. Berlin: Edition Sigma.

Depenheuer, Otto (1996): Bürgerverantwortung im demokratischen Verfassungsstaat. In: VVDStRL 55, 90-127.

Dingeldey, Irene (2005): Wandel von Governance im Sozialstaat: zur Implementation aktivierender Arbeitsmarktpolitik in Deutschland, Dänemark und Großbritannien. SFB 597 „Staatlichkeit im Wandel“ Working Paper 12. Universität Bremen.

Dyson, Kenneth (2005): Authoritative and Reflexive Strategies for Binding Hands: Europeanization, Government by Commission, and Economic Reform. In: German Politics 14 (2), 224-247.

Eichhorst, Werner (2006): Beschäftigung Älterer in Deutschland: der unvollständige Paradigmenwechsel. In: Zeitschrift für Sozialreform 52 (1), 101-123.

Eichhorst, Werner/Profit, Stefan/Thode, Eric (2001): Benchmarking Deutschland: Arbeitsmarkt und Beschäftigung. Berlin: Springer.

Eichhorst, Werner/Kaiser, Lutz C. (2006): The German Labour Market: Still Adjusting Badly? IZA Discussion Paper 2215. Bonn: IZA.

Eichhorst, Werner/Schneider, Hilmar/Zimmermann, Klaus F. (2006): Konzentration statt Verzettelung: Die deutsche Arbeitsmarktpolitik am Scheideweg. In: Perspektiven der Wirtschaftspolitik 7 (3), 379-397.

Eichhorst, Werner/Sesselmeier, Werner (2006): Die Akzeptanz von Arbeitsmarktreformen am Beispiel von Hartz IV. Bonn: Friedrich Ebert Stiftung.

Eichhorst, Werner/Konle-Seidl, Regina (2007, forthcoming): The Interaction of Labour Market Regulation and Labour Market Policies in Welfare State Reform. In: Comparative Labour Law and Social Policy J ournal.

Enderlein, Wolfgang (1996): Rechtspaternalismus und Vertragsrecht. München: C. H. Beck.

Esping-Andersen, Gøsta (1990): The Three Worlds of Welfare Capitalism. Princeton: Princeton University Press.

Esping-Andersen, Gøsta (1996): Welfare States Without Work: the Impasse of Labour Shedding and Familialism in Continental European Social Policy. In: Esping-Andersen, Gøsta (Ed.): Welfare States in Transition. National Adaptations in Global Economies. London: Sage, 66-87. 
Estevez-Abe, Margarita/Iversen, Torben/Soskice, David (2001): Social Protection and the Formation of Skills. In: Hall, Peter A. /Soskice, David (Eds.): Varieties of Capitalism: The Institutional Foundations of Comparative Advantage. Oxford: Oxford University Press, 145-183.

Fahr, René/Sunde, Uwe (2006): Did the Hartz Reforms Speed-Up J ob Creation? A Macro-Evaluation Using Empirical Matching Functions. IZA Discussion Paper 2470. Bonn: IZA.

Fichtner, Otto (2003): Bundessozialhilfegesetz. München: Verlag Franz Vahlen.

Fleckenstein, Timo (2004): Policy-Lernen in der Arbeitsmarktpolitik: das Beispiel der Hartz-Kommission. In: Zeitschrift für Sozialreform 50 (6), 646-675.

Gagel, Alexander (Ed.) (2005): Sozialgesetzbuch III - Arbeitsförderung. München: C. H. Beck.

Giddens, Anthony (1999): Der dritte Weg: die Erneuerung der sozialen Demokratie. Frankfurt: Campus.

Graf, Tobias/Rudolph, Helmut (2006): Bedarfsgemeinschaften im SGB II 2005: Beachtliche Dynamik bei steigenden Empfängerzahlen. IAB Kurzbericht 23/2006. Nürnberg: IAB.

Groner-Weber, Sabine (2000): Der aktivierende Staat - Konzepte und Entwicklungsoptionen. In: Metzger, Erika/West, Klaus-W. (Eds.): Aktivierender Sozialstaat und politisches Handeln. Marburg: Schüren, 167172.

Hartz, Peter et al. (2002): Moderne Dienstleistungen am Arbeitsmarkt. Berlin: Bundesministerium für Arbeit und Sozialordnung.

Henneke, Hans-Günther (2005): Aufgabenwahrnehmung und Finanzlastverteilung im SGB II als Verfassungsproblem. In: Die öffentliche Verwaltung, 177-191.

Henneke, Hans-Günter (2006): Hartz IV in der „Überholung“: Die Suche nach klarer Verantwortungszuordnung in den Arbeitsgemeinschaften geht weiter. In: Die öffentliche Verwaltung, 726-732.

Höfling, Wolfram (1991): Vertragsfreiheit: Eine grundrechtsdogmatische Studie. Heidelberg: Müller Verlag.

Hunt, Jennifer (1995): The effect of unemployment compensation on unemployment duration in Germany. In: Journal of Labor Economics, 13 (1), 88-120.

Hüttenbrink, Jost (2004): Sozialhilfe und Arbeitslosengeld II, Hilfe zum Lebensunterhalt, Grundsicherung, sonstige Ansprüche, Verfahren, Verwandtenregress. München: dtv. 
Jacobi, Lena/Kluve, J ochen (2006): Before and After the Hartz Reforms: The Performance of Active Labour Market Policy in Germany. IZA Discussion Paper 2100. Bonn: IZA.

Jann, Werner/Schmid, Günther (Eds.) (2004): Eins zu eins? Eine Zwischenbilanz der Hartz-Reformen am Arbeitsmarkt. Berlin: Edition Sigma.

Jantz, Bastian (2004): Zusammenführung von Arbeitslosen- und Sozialhilfe, in: Jann, Werner/Schmid, Günther (Eds.) (2004): Eins zu eins? Eine Zwischenbilanz der Hartz-Reformen am Arbeitsmarkt. Berlin: Edition Sigma, 38-50.

Kaltenborn, Bruno/Schiwarov, Juliana (2006a): Hartz IV: Deutlich mehr Fürsorgeempfänger/innen. Blickpunkt Arbeit und Wirtschaft 5/2006. Berlin.

Kaltenborn, Bruno/Schiwarov, Juliana (2006b): Hartz IV: Ausgaben deutlich unterschätzt. Blickpunkt Arbeit und Wirtschaft 6/2006. Berlin.

Kaltenborn, Bruno/Knerr, Petra/Schiwarov, Juliana (2006): Hartz IV: Leistungen von Arbeitsgemeinschaften und Optionskommunen. Blickpunkt Arbeit und Wirtschaft 8/2006. Berlin.

Karl, Astrid/Ullrich, Carsten G./Hamann, Silke (2002): Akzeptanz und Akzeptanzunterschiede von Arbeitslosenversicherung und Sozialhilfe. In: Sozialer Fortschritt 48 (1), 53-75.

Knuth, Mathias (2006): „Hartz IV“ - die unbegriffene Reform. In: Sozialer Forstschritt 52 (7), 160-168.

Knoblauch, Dieter/Hübner, Torsten (2006): Hartz IV - ein Vermögensbildungsprogramm für selbständig Erwerbstätige? In: Nachrichtendienst des Deutschen Vereins für öffentliche und private Fürsorge, 375-379.

Koch, Susanne/Walwei, Ulrich (2005): Hartz IV: Geht die Reform zu weit oder noch nicht weit genug? In: Wirtschaftsdienst 85 (7), 411-417.

Köhler, Hajo (2005): Arbeitsförderungsrecht. In: Plagemann, Hermann/ Ehmann, Frank: Münchener Anwaltshandbuch Sozialrecht. München: C.H. Beck, §§ 12 - 15.

Konle-Seidl, Regina (2005a): New Delivery Forms of Employment Services in Germany: A Mixed Public-Private Model? In: Sol, Els/Westerveld, Mies (Eds.): Contractualism in Employment Services. A New Form of Welfare State Governance. The Hague: Kluwer Law, 187-207.

Konle-Seidl, Regina (2005b): Arbeitsvermittlung zwischen Zentralisierung, Kommunalisierung und Privatisierung. In: Wirtschaftsdienst 85 (9), 575-581. 
Konle-Seidl, Regina/Lang, Kristina (2006): Von der Reduzierung zur Mobilisierung des Arbeitskräftepotenzials. IAB Forschungsbericht 15/2006. Nürnberg: IAB.

Konle-Seidl, Regina/Schewe, Torben (2007, forthcoming): Operational use of Evaluation Results in the Restructured German PES. In: Di Domenico, Germana/Spattini, Silvia (Eds.): New European approaches to longterm unemployment. Which role for public employment services and what market for private stakeholders? The Hague: Kluwer Law.

Krahmer, Utz (2004): Verfassungsrechtliche Bedenken gegen die HartzIV- Gesetze (SGB II und SGB XII), insbesondere das Beispiel ungedeckten Bedarfs der Hilfe zum Lebensunterhalt bei nicht angespartem oder abhanden gekommenem Arbeitslosengeld II - zugleich ein Beitrag zu $\S 5$ Abs. 2 S. 1 SGB II sowie zu § 21 S. 1 SGB XII. In: Zeitschrift für das Fürsorgewesen, 178-182.

Launov Andrey, Wolff J oachim, Klasen, Stephan (2004): Unemployment Benefits and Unemployment Rates of Low-Skilled and Elder Workers in West Germany: A Search Equilibrium Approach. IZA-Discussion Paper No. 1161

Ludwig-Mayerhofer, Wolfgang (2005): Activating Germany. In: Bredgaard, Thomas/Larsen, Flemming (Eds.) Employment Policy From Different Angles. Copenhagen: DJ OF Publishing, 95-114.

Lühmann, Hans (2004): Verfassungswidrige Zusammenlegung von Arbeitslosen- und Sozialhilfe im SGB II? Eine organisationsrechtliche Analyse. In: Die öffentliche Verwaltung, 677-685.

Luthe, Ernst-Wilhelm (2003): Der aktivierende Sozialstaat im Recht. In: Nachrichtendienst des Deutschen Vereins für öffentliche und private Fürsorge, 167-177.

Neumann, Volker (1995): Menschenwürde und Existenzminimum. In: Neue Zeitschrift für Verwaltungsrecht, 426 ff.

Manow, Philip/Seils, Eric (2000): Adjusting Badly: The German Welfare State, Structural Change, and the Open Economy. In: Scharpf, Fritz W. und Schmidt, Vivien A. (Eds.): Welfare and Work in the Open Economy, Vol 2. Oxford: Oxford University Press, 264-307.

Mezger, Erika/West, Klaus-W. (Eds.) (2000): Aktivierender Sozialstaat und politisches Handeln. Marburg: Schüren.

Müller, Kai-Uwe/Oschmiansky, Frank (2005): Die Sanktionspolitik der Arbeitsagenturen: eine empirische Analyse zu Sperrzeiten. n: Schütz, Holger/Mosley, Hugh (Eds.): Arbeitsagenturen auf dem Prüfstand - Leistungsvergleich und Reformpraxis der Arbeitsvermittlung. Berlin: Edition Sigma, 95-134.

OECD (2004): Benefits and Wages. OECD Indicators 2004. Paris. 
Oestreicher, Ernst (Ed.) (2006): SGB XII/SGB II, Kommentar. München: C. H. Beck.

Oppermann, Dagmar (2005): Verfassungsrechtliche Fragen zur Finanzierung der Grundsicherung für Arbeitsuchende. In: Deutsches Verwaltungsblatt, 1008-1014.

O'Sullivan, Daniel (2005): Verfassungsrechtliche Fragen des Leistungsrechts der Grundsicherung für Arbeitsuchende. In: Die Sozialgerichtsbarkeit, 369 - 376.

Papier, Hans-J ürgen (2003): Der Einfluss des Verfassungsrechts auf das Sozialrecht, in: Maydell, Bernd von/Ruland, Franz: Sozialrechtshandbuch. Baden - Baden: Nomos, A 3.

Quaas, Michael (2004): Die Arbeitsgemeinschaft nach dem neuen SGB II: Ungelöste Rechtsfragen zur Rechtsnatur der Einrichtung. In: Die Sozialgerichtsbarkeit, 723-729.

Rothkegel, Ralf (Ed.) (2005): Sozialhilferecht: Existenzsicherung, Grundsicherung. Baden-Baden: Nomos.

Rucht, Dieter/Yang, Mundo (2004): „Wer demonstrierte gegen Hartz IV?“ In: Forschungsjournal Neue Soziale Bewegungen, Sonderdruck, Dezember 2004, 21-27.

Ruge, Kay/Vorholz, Irene (2005): Verfassungs- und verwaltungsrechtliche Fragestellungen bei der Arbeitsgemeinschaft nach § 44b SGB II. In: Deutsches Verwaltungsblatt, 403-415.

Sartorius, Ulrich (2005): Höhere Regelleistungen und Regelsätze im Klagewege? In: Informationen zum Arbeitslosenrecht und Sozialhilferecht, 56-58.

Sachverständigenrat zur Begutachtung der gesamtwirtschaftlichen Entwicklung (2006): Arbeitslosengeld II reformieren: Ein zielgerichtetes Kombilohnmodell. Expertise im Auftrag des Bundesministeriums für Wirtschaft und Technologie. Wiesbaden, August 2006

Scharpf, Fritz W. (1997): Employment and the Welfare State. A Continental Dilemma. MPIfG Working Paper 97/7. Köln: Max Planck Institute for the Study of Societies.

Schneider, Hilmar/Lang Cornelia, Rosenfeld Martin/ Kempe Wolfram/Kolb Jürgen (2002): Anreizwirklungen der Sozialhilfe auf das Arbeitsangebot im Niedriglohnbereich. Schriften des Instituts für Wirtschaftsforschung Halle Bd. 12. Baden-Baden: Nomos-Verlag.

Schröder, Gerhard/Blair, Tony (1999): Der Weg nach vorn für Europas Sozialdemokraten, Juni 1999. 
Seewald, Ottfried (1997): Eingriffe in die Berufsfreiheit durch neue Qualifikationsvoraussetzungen (am Beispiel des § 35a Abs. 6 SGB IV). In: Neue Zeitschrift für Sozialrecht, 345-354.

Spannowsky, Willy (1994): Grenzen des Verwaltungshandelns durch Verträge und Absprachen. Berlin: Duncker \& Humblot.

Stahlmann, Günther (2006): 1 - Euro - Jobs zwischen Arbeitsvermittlung und Abstellgleis. In: Zeitschrift für Sozialhilfe und Sozialgesetzbuch, 131-143.

Steiner, Victor (1997): Extended benefit-entitlement periods and the duration of unemployment in West Germany. Center for European Economic Research Discussion Paper No 97-14.

Streeck, Wolfgang (2001): High Equality, Low Activity: The Contribution of the Social Welfare System to the Stability of the German Collective Bargaining Regime. Review Symposium on Harry C. Katz and Owen Darbishire, Converging Divergences: Worldwide Changes in Employment Systems. In: Industrial and Labour Relations Review 54 (3), 698706.

Streeck, Wolfgang (1997): German Capitalism. Does it Exist? Can it Survive? In: Crouch, Colin/Streeck, Wolfgang (Eds.): The Political Economy of Modern Capitalism. Mapping Convergence and Diversity. London: Sage, 33-54.

Streeck, Wolfgang/Trampusch, Christine (2005): Economic Reform and the Political Economy of the German Welfare State. In: German Politics 14 (2), 174-195.

Trampusch, Christine (2002): Die Bundesanstalt für Arbeit und das Zusammenwirken von Staat und Verbänden in der Arbeitsmarktpolitik von 1952 bis 2001. MPIfG Working Paper 02/5.

Trube, Achim (2003): Aktivierender Sozialstaat - Programmatik, Praxis und Probleme. In: Nachrichtendienst des Deutschen Vereins für öffentliche und private Fürsorge, 334-341.

Wilke, Ralf A. (2003): Eine empirische Analyse von Sanktionen für Arbeitslose in Westdeutschland während der 1980er und 1990er Jahre. ZEW Discussion Paper 03-71. Mannheim: ZEW.

Wolff, J oachim/Hohmeyer Katrin (2006): Förderung von arbeitslosen Personen im Rechtskreis des SGB II durch Arbeitsgelegenheiten: Bislang wenig zielgruppenorientiert. IAB Forschungsbericht 10/2006. Nürnberg: IAB.

Wunder, Annett/Diehm, Alexander (2006): SGB II - Fortentwicklungsgesetz verschärft die Sanktionen: Sind Kürzungen des Arbeitslosengeldes Il um bis zu 100 Prozent verfassungswidrig? In: Soziale Sicherheit, 195-199. 
Zacher, Hans F. (2004): Das soziale Staatsziel. In: I sensee, Josef/Kirchhof, Paul (Eds.): Handbuch des Staatsrechts, Vol. 2. Heidelberg: C. F. Müller Verlag, § 28.

Zwanziger, Bertram (2005): Rechtliche Rahmenbedingungen für "Ein Euro - Jobs". In: Arbeit und Recht, 8-15. 


\section{Recently published}

\begin{tabular}{|c|c|c|c|}
\hline No. & Author(s) & Title & Date \\
\hline $1 / 2004$ & $\begin{array}{l}\text { Bauer, T. K. } \\
\text { Bender, S. } \\
\text { Bonin, H. }\end{array}$ & $\begin{array}{l}\text { Dismissal protection and worker flows in small establish- } \\
\text { ments } \\
\text { published in: Economica }\end{array}$ & $7 / 04$ \\
\hline$\underline{2 / 2004}$ & $\begin{array}{l}\text { Achatz, J. } \\
\text { Gartner, H. } \\
\text { Glück, T. }\end{array}$ & $\begin{array}{l}\text { Bonus oder Bias? : Mechanismen geschlechtsspezifischer } \\
\text { Entlohnung } \\
\text { published in: Kölner Zeitschrift für Soziologie und Sozialpsy- } \\
\text { chologie } 57 \text { (2005), S. } 466-493 \text { (revised) }\end{array}$ & $7 / 04$ \\
\hline$\underline{3 / 2004}$ & $\begin{array}{l}\text { Andrews, M. } \\
\text { Schank, T. } \\
\text { Upward, R. }\end{array}$ & $\begin{array}{l}\text { Practical estimation methods for linked employer-employee } \\
\text { data }\end{array}$ & $8 / 04$ \\
\hline$\underline{4 / 2004}$ & $\begin{array}{l}\text { Brixy, U. } \\
\text { Kohaut, S. } \\
\text { Schnabel, C. }\end{array}$ & $\begin{array}{l}\text { Do newly founded firms pay lower wages? : first evidence } \\
\text { from Germany } \\
\text { published in: Small Business Economics, (2007) }\end{array}$ & $9 / 04$ \\
\hline$\underline{5 / 2004}$ & $\begin{array}{l}\text { Kölling, A. } \\
\text { Rässler, S. }\end{array}$ & $\begin{array}{l}\text { Editing and multiply imputing German establishment panel } \\
\text { data to estimate stochastic production frontier models } \\
\text { published in: Zeitschrift für ArbeitsmarktForschung } 37 \text { (2004), } \\
\underline{\text { S. } 306-318}\end{array}$ & $10 / 04$ \\
\hline$\underline{6 / 2004}$ & $\begin{array}{l}\text { Stephan, G. } \\
\text { Gerlach, K. }\end{array}$ & $\begin{array}{l}\text { Collective contracts, wages and wage dispersion in a multi- } \\
\text { level model } \\
\text { published as: Wage settlements and wage setting : results } \\
\text { from a multi-level model. In: Applied Economics, Vol. } 37 \text {, No. } \\
\underline{20(2005), \text { S. } 2297-2306}\end{array}$ & $10 / 04$ \\
\hline$\underline{7 / 2004}$ & $\begin{array}{l}\text { Gartner, H. } \\
\text { Stephan, G. }\end{array}$ & $\begin{array}{l}\text { How collective contracts and works councils reduce the gen- } \\
\text { der wage gap }\end{array}$ & $12 / 04$ \\
\hline$\underline{1 / 2005}$ & $\begin{array}{l}\text { Blien, U. } \\
\text { Suedekum, J. }\end{array}$ & $\begin{array}{l}\text { Local economic structure and industry development in Ger- } \\
\text { many, 1993-2001 }\end{array}$ & $1 / 05$ \\
\hline$\underline{2 / 2005}$ & $\begin{array}{l}\text { Brixy, U. } \\
\text { Kohaut, S. } \\
\text { Schnabel, C. }\end{array}$ & $\begin{array}{l}\text { How fast do newly founded firms mature? : empirical analy- } \\
\text { ses on job quality in start-ups } \\
\text { published in: Michael Fritsch, Jürgen Schmude (Ed.): Entre- } \\
\text { preneurship in the region, New York et al., 2006, S. 95-112 }\end{array}$ & $1 / 05$ \\
\hline$\underline{3 / 2005}$ & $\begin{array}{l}\text { Lechner, M. } \\
\text { Miquel, R. } \\
\text { Wunsch, C. }\end{array}$ & $\begin{array}{l}\text { Long-run effects of public sector sponsored training in West } \\
\text { Germany }\end{array}$ & $1 / 05$ \\
\hline 4/2005 & Hinz, T. & Lohnunterschiede zwischen Frauen und Männern in Bran- & \\
\hline
\end{tabular}


Gartner, $\mathrm{H}$. chen, Berufen und Betrieben

published in: Zeitschrift für Soziologie 34 (2005), S. 22-39,

as: Geschlechtsspezifische Lohnunterschiede in Branchen,

Berufen und Betrieben

$\underline{5 / 2005}$ Gartner, H.

Analyzing the changing gender wage gap based on multiply

Rässler, S. imputed right censored wages

6/2005 Alda, $\mathrm{H}$.

The linked employer-employee dataset of the IAB (LIAB)

Bender, S.

published as: The linked employer-employee dataset created

Gartner, $\mathrm{H}$. from the IAB establishment panel and the process-produced data of the IAB (LIAB). In: Schmollers Jahrbuch. Zeitschrift für Wirtschafts- und Sozialwissenschaften 125 (2005), S. 327$\underline{336 \text { (shortened) }}$

7/2005 Haas, A.

Labour market dynamics from a regional perspective : the

Rothe, $\mathrm{T}$.

multi-account system

8/2005 Caliendo, M.

Identifying effect heterogeneity to improve the efficiency of

Hujer, R.

job creation schemes in Germany

Thomsen, S. L.

9/2005 Gerlach, K.

Wage distributions by wage-setting regime

Stephan, G.

published as: Bargaining regimes and wage dispersion. In:

Jahrbücher für Nationalökonomie und Statistik, Bd. 226, H. 6 (2006)

10/2005 Gerlach, K.

Individual tenure and collective contracts

Stephan, G.

$\underline{11 / 2005}$ Blien, U.

Formula allocation : the regional allocation of budgetary funds

for measures of active labour market policy in Germany

$\underline{12 / 2005}$ Alda, $\mathrm{H}$.

Churning and institutions : Dutch and German establishments

Allaart, $\mathrm{P}$.

compared with micro-level data

Bellmann, L.

$\underline{13 / 2005}$ Caliendo, M.

Individual employment effects of job creation schemes in

Hujer, R.

Germany with respect to sectoral heterogeneity

Thomsen, S. L.

14/2005 Lechner, M.

The curse and blessing of training the unemployed in a

Miquel, $\mathrm{R}$.

changing economy : the case of East Germany after unifica-

Wunsch, C.

tion

$\underline{15 / 2005}$ Jensen, U.

Where have all the data gone? : stochastic production fron-

Rässler, S.

tiers with multiply imputed German establishment data

published in: Zeitschrift für ArbeitsmarktForschung, Jg. 39, H. 
16/2005 Schnabel, C. Collective bargaining structure and its determinants : an em-

Zagelmeyer, S. pirical analysis with British and German establishment data

Kohaut, S.

published in: European Journal of Industrial Relations, Vol.

12 , No. 2. S. $165-188$

$\underline{17 / 2005}$ Koch, S.

Workfare: Möglichkeiten und Grenzen

$8 / 05$

Stephan, G.

published in: Zeitschrift für ArbeitsmarktForschung 38 (2005),

Walwei, U.

S. $419-440$

$\underline{18 / 2005}$ Alda, $\mathrm{H}$.

Wage structure and labour mobility in the West German pri-

Bellmann, L.

vate sector 1993-2000

Gartner, $\mathrm{H}$.

$\underline{19 / 2005}$

Eichhorst, W

The interaction of labor market regulation and labor market

Konle-Seidl, R

policies in welfare state reform

20/2005 Gerlach, K.

Tarifverträge und betriebliche Entlohnungsstrukturen

Stephan, G.

published in: C. Clemens, M. Heinemann \& S. Soretz (Hg.):

Auf allen Märkten zu Hause, Marburg 2006, S. 123-143

21/2005 Fitzenberger, B. Employment effects of the provision of specific professional

Speckesser, S. $\quad$ skills and techniques in Germany

22/2005 Ludsteck, J. Strike activity and centralisation in wage setting

Jacobebbinghaus, $\mathrm{P}$.

$\underline{1 / 2006}$

Gerlach, K.

The acceptability of layoffs and pay cuts : comparing North

Levine, D.

America with Germany

Stephan, G.

Struck, O.

2/2006 Ludsteck, J.

Employment effects of centralization in wage setting in a median voter model

3/2006 Gaggermeier, C. Pension and children : Pareto improvement with heterogeneous preferences

4/2006 Binder, J. Korrekturverfahren zur Berechnung der Einkommen über der

Schwengler, B. Beitragsbemessungsgrenze

5/2006 Brixy, U.

Regional patterns and determinants of new firm formation

Grotz, R.

and survival in western Germany

6/2006 Blien, U.

Structural change and regional employment dynamics

Sanner, $\mathrm{H}$.

7/2006 Stephan, G.

Wirkungsanalyse in der Bundesagentur für Arbeit : Konzepti-

Rässler, S. on, Datenbasis und ausgewählte Befunde

Schewe, $\mathrm{T}$.

published as: Das TrEffeR-Projekt der Bundesagentur für

Arbeit : die Wirkung von Maßnahmen aktiver Arbeitsmarktpo- 
litik. In: Zeitschrift für ArbeitsmarktForschung, Jg. 39, H. 3/4

$\underline{(2006)}$

8/2006 Gash, V.

Mertens, A.

Romeu Gordo, L.

9/2006 Romeu Gordo, L.

10/2006 Jahn, E. J.

Wagner, $\mathrm{T}$.

$\underline{11 / 2006}$ Jensen, U.

Gartner, $\mathrm{H}$.

Rässler, S.

12/2006 Meyer, B.

Lutz, C.

Schnur, P.

Zika, G.

13/2006 Beblo, M.

Bender, S.

Wolf, E.

14/2006 Niebuhr, A.

15/2006 Kiesl, H.

Rässler, S.

16/2006 Hujer, R.

Zeiss, C.

17/2006 Fitzenberger, B. Osikominu, A.

Völter, R.

18/2006 Antoni, M.

Jahn, E. J.

19/2006 Fuchs, J.

Söhnlein, D.

20/2006 Lechner, M.

Wunsch, C.

21/2006 Kruppe, T.
Are fixed-term jobs bad for your health? : a comparison of

West-Germany and Spain

Compression of morbidity and the labor supply of older peo-

$5 / 06$ ple

Base period, qualifying period and the equilibrium rate of

$6 / 06$ unemployment

Measuring overeducation with earnings frontiers and multiply

$6 / 06$

imputed censored income data

National economic policy simulations with global interde-

$7 / 06$

pendencies : a sensitivity analysis for Germany

The wage effects of entering motherhood : a within-firm mat-

$8 / 06$

ching approach

Migration and innovation : does cultural diversity matter for

$8 / 06$

regional $R \& D$ activity?

How valid can data fusion be?

$8 / 06$

The effects of job creation schemes on the unemployment

$8 / 06$

duration in East Germany

Get training or wait? : long-run employment effects of training

9/06

programs for the unemployed in West Germany

Do changes in regulation affect employment duration in tem-

9/06

porary work agencies?

Effekte alternativer Annahmen auf die prognostizierte Er-

$10 / 06$

werbsbevölkerung

Active labour market policy in East Germany : waiting for the

economy to take off

Die Förderung beruflicher Weiterbildung : eine mikroökono-

Programm 
$\underline{22 / 2006}$ Feil, M.

Klinger, S.

Zika, G.

23/2006 Blien, U.

Phan, t. H. V.

$\underline{24 / 2006}$ Lutz, R.

25/2006 Jirjahn, U.

Pfeifer, C.

Tsertsvadze, G.

$\underline{26 / 2006}$ Rudolph, $\mathrm{H}$.

$\underline{27 / 2006}$ Wolff, J.

28/2006 Blien, U.

Kirchhof, K.

Ludewig, $\mathrm{O}$.

29/2006 Blien, U.

Hirschenauer, F.

Phan, t. H. V.

$\underline{30 / 2006}$ Krug, G.

$\underline{1 / 2007}$ Moritz, M.

Gröger, M.

2/2007 Hampel, K.

Kunz, M.

Schanne, N.

Wapler, R.

Weyh, A.

3/2007 Eckey, H.- F. Schwengler, B.

Türck, M.

4/2007 Kristen, C. Granato, N.
Sozialabgaben und Beschäftigung : Simulationen mit drei

$11 / 06$ makroökonomischen Modellen

A pilot study on the Vietnamese labour market and its social and economic context

Was spricht eigentlich gegen eine private Arbeitslosenversicherung?

Mikroökonomische Beschäftigungseffekte des Hamburger

$11 / 06$

Modells zur Beschäftigungsförderung

Indikator gesteuerte Verteilung von Eingliederungsmitteln im

$12 / 06$ SGB II : Erfolgs- und Effizienzkriterien als Leistungsanreiz? How does experience and job mobility determine wage gain in a transition and a non-transition economy? : the case of east and west Germany

Agglomeration effects on labour demand

Model-based classification of regional labour markets : for

$12 / 06$

purposes of labour market policy

Kombilohn und Reziprozität in Beschäftigungsverhältnissen :

eine Analyse im Rahmen des Matching-Ansatzes

The German-Czech border region after the fall of the Iron

Curtain: Effects on the labour market : an empirical study using the IAB Employment Sample (IABS)

Regional employment forecasts with spatial interdependencies

Vergleich von deutschen Arbeitsmarktregionen

The educational attainment of the second generation in Ger- 
$\underline{5 / 2007}$ Jacob, M.

Kleinert, C.
Does unemployment help or hinder becoming independent? :

$1 / 07$

Stand: 29.1.2007 


\section{IABDiscussionPaper}

No. 6 / 2007

\section{Editorial address}

Institut für Arbeitsmarkt- und Berufsforschung der Bundesagentur für Arbeit

Weddigenstr. 20-22

D-90478 Nürnberg

\section{Editorial staff}

Regina Stoll, Jutta Palm-Nowak

\section{Technical completion}

Jutta Sebald
All rights reserved

Reproduction and distribution in any form, also in parts, requires the permission of IAB Nürnberg

Download of this DiscussionPaper:

http://doku.iab.de/discussionpapers/2007/dp0607.pdf

\section{Website}

http://www.iab.de

For further inquiries contact the author:

Regina Konle-Seidl, Tel. 0911/179-3244,

or e-mail: regina.konle-seidl@iab.de 